\title{
Siberi eestlaste surma- ja matusekombestikust 20. sajandi viimasel kümnendil
}

Anu Korb

\begin{abstract}
Teesid
Mõiste Siberi eestlased hõlmab nii 18.-19. sajandil Vene tsaari poolt väljasaadetute kui 19. sajandi viimasel kümnendil ja 20. sajandi algupoolel väljarännanute järglased.

Artiklis käsitlen Siberi eesti kogukondade surma- ja matusekombestikku suremise momendist kuni matusetalituse ja peielauani ning hilisemaid mälestuspäevi. Materjal on kogutud Eesti Rahvaluule Arhiivi ekspeditsioonidel (aastatel 1991-2000) nii kesk- ja vanemaealisi eestlasi küsitledes kui kohapeal Siberi eestlaste kalmistukultuuri, mälestuspäevi jms jälgides.

Artiklis vaadeldakse, kuidas toimib Siberi eestlaste kogukond usulise süsteemi purustamise olukorras: mil määral matusekombestiku suhteline konservatiivsus tingib väljakujunenud tavade jätkamise, kuidas muutunud oludes esilekerkinud külamatjad kombestikku suunavad ning missugused kombestikuosad teisenevad keskkonna paljurahvuseliseks muutudes.
\end{abstract}

Märksõnad: matja, matusekombestik, mälestuspäevad, Siberi eestlased, surm.

Siberi eestlasteks peetakse 18.-19. sajandil kodumaalt väljasaadetute ning 19. sajandi viimasel kümnendil ja 20. sajandi algupoolel viletsuse sunnil n-ö vabatahtlikult väljarännanute järglasi. 1989. aasta rahvaloenduse andmetel elas Siberis veel 17000 eestlast.

Aastatel 1991-2000 külastasin Eesti Rahvaluule Arhiivi ekspeditsioonirühma koosseisus Siberi eestlaste asualasid maapiirkondades Omski oblastist Krasnojarski kraini. Eesti keelt kuulsime umbes 30 Siberi külas, kuid enam-vähem eestikeelsetena leidsime eest kuus küla: Lillikülä, Estonka ja Jurjevka Omski oblasti Tara piirkonnas, Nikolajevka Novosibirski oblasti Kõštovski rajoonis, Jurjevka Kemerovo oblasti Mariinski rajoonis ning Ülem-Suetuki Karasnojarski krai Minussiinski piirkonnas. Enamikust endistest eesti asundustest on nüüdseks saanud paljurahvuselised külad, kus üldiseks suhtluskeeleks on vene keel.

Osa endisi eesti külasid asub üksteisele võrdlemisi lähedal (nt Mariinski piirkonna Jurjevka ja Koidula, Tara piirkonna Lillikülä ja Estonka, Omi jõe ümbruse külad) ning nende elanikud suhtlevad 


\section{Anu Korb}

omavahel aktiivselt, mõne küla naabruses (nt Nikolajevka, Rõžkovo) elavad vaid mitte-eestlased ja eesti keeles saab suhelda üksnes oma kodukohas. Tüüpiline on, et elanike keelekasutuse järgi võib siiani tuvastada väljarännanute lõuna- või põhjaeestilist päritolu, sest selliste külade tuumik koosnes peamiselt ühe piirkonna asukatest, väljasaadetud olid aga pärit Eesti erinevatest paikadest ning neil on võõrsil tekkinud põhjaeesti murretel põhinev ühiskeel, millele Eestis täpset vastet ei leidu.

Kuni 1930. aastateni elati asundustes oma keelt ja kultuuritraditsioone austades: olid oma koolid, seltsid, üheks identiteedimäärajaks oli ja on ka praegu luteri usk. Kunagine kiriklik kuuluvus on nii määrav, et teistest rahvustest luterlasi (lätlased, soomlased, sakslased) peetakse senini rohkem omadeks kui õigeusklikke. Usuelu, hiljem ka rahvuskoolide keelustamine, ühismajandite moodustamine ja repressioonid halvasid väljakujunenud elulaadi. Pärast Teist maailmasõda algas väikeste külade hääbumine. Suuremad külad muutusid paljurahvuselisteks. Sõjajärgsel nõukogude ajal suheldi kodueestlastega aktiivselt: sugulased käisid vastastikku külas, peeti kirjavahetust, saadeti pakke. Pärast Eesti Vabariigi taasiseseisvumist on Kodu-Eestiga suhtlemine harvenenud eelkõige majanduslikel põhjustel.

Kuna varasemad ülestähendused Siberi eestlastelt peaaegu puuduvad, saan sealsete eestlaste surma- ja matusekombestikku käsitleda vaid aastatel 1991-2000 kogutu põhjal ning kaheksa-üheksa aastat varem asundustes käinud keeleteadlaste uurimusi arvesse võttes. Vaid Krasnojarski krai eestlaste matusekombestiku kohta leidub teavet ka veidi varasemast ajast - Eesti Rahvaluule Arhiivi korrespondendi Rosalie Ottessoni saadetistes aastatest 1969-1976.

Küsitletud valdasid üldjuhul eesti keelt ning olid enamasti keskja vanemaealised. Igaüks neist oskas mingil määral surma- ja matusekombestiku osas kaasa rääkida. Enim informatsiooni sain matusetalituse läbiviijailt, kes kõige paremini surmaga seotud traditsiooni tunnevad ja seda ka ise kujundavad. Osaleja-vaatlejana viibisin ka 2000. aasta hilissuvel Zolotaja Niva küla vanima eesti mehe matustel, kes suri 84-aastasena, ning 1998. aastal Borovuška külas üheksa päeva eest surnu mälestuspäeval. Ekspeditsioonidel olen jälginud ka Siberi eestlaste kalmistukultuuri (v.a talvistel ekspeditsioonidel 1992., 1993. ja 1997. aastal) ning pühadeaegseid kalmistul käimisi (nt surnute mälestuspäev Zolotaja Niva külas 1995. aasta kevadel, võidu- 


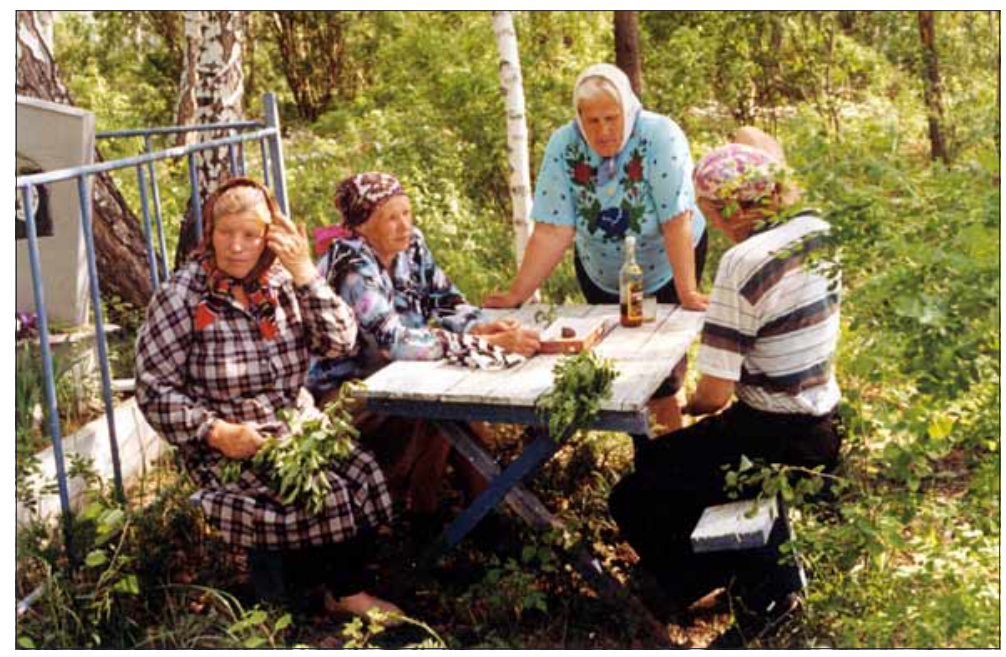

Foto 1. Suvistepüha Rosentali külakalmistul. Anu Korbi foto 1999. (ERA, vf 1674).

püha Semjonovka külakalmistul 9. mail 1995, lihavõtted Mihhailovkas 1996. aastal ja suvistepühad Rosentalis 1999. aastal).

Artiklis annan ülevaate Siberi eestlaste surma- ja matusekombestikust suremise momendist kuni matusetalituse ja peielauani ning hilisematest mälestuspäevadest. Esile on toodud ka surnuga kokkupuutes olnud esemete maagilised kasutusviisid ja -võtted.

\section{Suremine, surnu majas}

Siberi eestlaste külakogukonnas võidakse tänapäevalgi elada suurperena, kuid järjest sagedamini lahkuvad täiskasvanud noored kodukülast linnadesse või rajoonikeskustesse. Külakogukonna vanemad liikmed ei jää hoolitsuseta ka siis, kui nende lähisugulased elavad kaugel. Venemaa külades toimib sotsiaalhoolekanne: vanainimestele, kes oma igapäevaste toimetustega enam hästi hakkama ei saa, määrab külanõukogu ametliku hooldaja ning seda tööd võetakse üpris tõsiselt. Siberi karmis kliimas on inimesed üldse harjunud enam kokku hoidma kui Kodu-Eestis ning naabrite abistamist peetakse enesestmõistetavaks. Surijat tema viimsetel tundidel enamasti üksi ei jäeta. 


\section{Anu Korb}

Surma lähedust ennustatakse Siberi eestlastelgi mitmesuguste üldtuntud märkide järgi: haige muutub rahutuks, tahab uut aset, tal tekib söögiisu. Enne surma võidakse näha teatud nägemusi:

Enne surõmist [näidatakse]. [---] Miis naisega lätsiva sanna. Ja naine tulli enne ärä ja miis jäi viil sanna. Ja miis tulle tarre, ütlese niimuudu, et mis sa ärä tullet, et mis luuma ma küll näin sannan! [---] A vot, määndene ta olli, vat toda es... Ütelse niimuudu, et mis sa ärä tullet, et mis luuma ma küll näin sannan! [---] A vot, määndene ta olli, vat toda es... Ütelse niimuudu, et näet, suresi ärä ja minul jäie küsimata, et määndene luum ta olli (FA DAT 54 (5) < Lillikülä k - Anu Korb < naine, s 1937 (1996)).

Üldtuntud on surija juures viibijatele kehtiv vaikusenõue, seda ka Siberi eestlastel:

Kui keegi hakkab surema, peab olema vagane, muidu hirmutad ta surmast ära. Mehevenna naine oli suremas. Ta tütar ehmatas: "Oi, mamma!" Ja tead, ta nädal aega ta mutšitas ${ }^{1}$ (EFA II 2, 217 (33) < Ivanovka k - Anu Korb < naine, s 1913 (1995)).

Samuti teavad Siberi eestlased, et surma kergendamiseks tuleb surija ase laetala järgi sättida:

Ja mõni ütles niiviisi, et laetala, mis om... vai kuiss teda kutsutas, matka vene keeli. Et ku sureja risti om taa tala all, tuu kavva elässi, ei lähe hing välla. Säng käänetass tõisi, selle tala järgi (FAM 140 (77) < Zolotaja Niva k - Anu Korb < naine, s 1916 (1995)).

Lae- ja katuselaudade avamine suremise kergendamiseks on laialt tuntud (vt nt Kemppinen 1967: 27). Hilisemal ajal on sama funktsiooni täitnud akna avamine surija toas (Mikkor 2001: 121). Üldiselt usutakse, et just nõidadel ja halbadel inimestel on raske surm. Ka Siberis arvatakse, et patune inimene sureb piinarikkalt:

Aga üteldas jaa, et nigu, kuis teda üteldi ennevanasti, et sa oled nigu pattu tennu, et siis surma voote pial sinnu piinatasse. Niiviisi minu vanempa kõneliva (FA DAT 48 (15) < Tara raj, Jurjevka k - Anu Korb < naine, s 1928 (1996)). 
Surnu majas kaetakse kinni peeglid. Varasemas Eestimaa traditsioonis arvati vastupeegelduses elav inimene surnu võimusesse sattuvat (Raadla 1939: 14-15). Tänapäeval ei osata peeglite katmist enamasti põhjendada ei Kodu-Eestis ega Siberiski. Tehakse nii, nagu vanemad on ees teinud, tava usundiline mõte on ununenud. Enamasti kehtib surnu majas ka töö- ja kolistamiskeeld. Sageli käivad töökeelud kogu küla kohta (Raadla 1939: 36; Reimann 1915: 146) ja puudutavad muu hulgas ka toiduainete konserveerimist-säilitamist. Siberi eestlastelt on teateid, et:

Kui surnu on külas, ei tohi kapsaid soolata ega kurki. [---] Ei ole midagi vaja soolata, ei saa ea (EFA I 19, 21 (71) < Tsvetnopolje k - Anu Korb < naine, s 1923 (1997)).

\section{Surnu pesemine, suririided. Hauapanused}

Siberi külas pestakse surnu tänini võimalikult kiiresti puhtaks. Eestimaalt saadud teated kinnitavad sama (vt nt Jannsen 1874: 302). Siinkohal on ilmselt tegemist puhtpraktilise põhjusega: kangestumata surnut on kergem pesta ja riietada. Marika Mikkori andmetel on Kaukaasia eestlaste, aga ka armeenlaste ja grusiinlaste seas tuntud ka mõnetunniline viivitamine surnu pesemisega (Mikkor 1994: 1243-1244). Pesemiseks kasutavad Siberi eestlased siiani enamasti vett ja seepi, mis on tuntud ka Kodu-Eesti varasemas traditsioonis. Merike Langi andmetel on mõnedes Ida-Virumaa piirkondades peetud lahkunu perekonnaliikmetele surnu pesemist otsese kontakti tõttu ohtlikuks (Lang 2004: 82). Siberi eestlased seda keeldu ei tunne - neil võivad surnut pesta nii lähisugulased kui võõrad, mõnes külas on olnud ka kutselisi surnupesijaid. Enamasti pesevad mehed meest ja naised naist. Mõnes Siberi külas on surnupesijad enamasti naised:

- A kes surnut peseb üldse?

- Ah keda kutsud.

- A kas on ükskõik, kas mees või naine või?

- No ei. Ikke naised, naised ikke pesevad rohkemb. Ei, mehi rohkem naised pesevad. Mehed ju ei pese, ei taha pesta. Sis rohkemb $i^{2}$ mehi naised (CD-0448 (37) < Rõžkovo k - Anu Korb < naine, s 1928 (2000)). 


\section{Anu Korb}

Surnupesijale antakse tasuks midagi surnu rõivastest, hilisemal ajal on antud ka raha. Raha andmata jätmine tähendavat surnupesijale kätevalu (Manninen 1924: 12). Tänapäeva Eestimaal kasutatakse surnu korrastamiseks üha sagedamini vastava asutuse, valdavalt matusebüroo teenust. Kui surnu pestakse kodus, puhastatakse ta enamasti viinalapiga. Just arenenud maades võib täheldada elavate eemaldumist surmast: surnu omaksed jätavad järjest sagedamini kõik surnuga seotud toimingud matusebüroo hooleks (vt nt Aho 1996: 119).

Surnupesuvesi valati enamasti kuhugi kõrvalisse kohta, et vältida selle peal tallamist ning selle tagajärjel haigestumist. Nii toimiti Kodu-Eestis (vt Raadla 1939: 21), Kaukaasia eestlaste juures (Mikkor 1994: 1246) ja Siberiski. Surnupesuveest võis mõnikord ka elavatele abi olla, nt elamusöödikute hävitamisel:

Kui viega surnut pestakse, sellega viega pesed tua ära, siis ei tule kirpusid ega lutikaid (RKM II 460, 318 (12) < Kaseküla k - Astrid Tuisk < naine, s 1921 (1993)).

Surnupesuveest on abi otsitud ka joodiku joomahoogude taltsutamiseks:

Kes on juodik, surnupesuvett antakse. Aga kas see aitab või ei, ei tea (RKM II 466, 531 (13) < Vambola k - Anu Korb < naine, s 1936 (1994)).

Varasemast Kodu-Eesti traditsioonist on teada, et surnu pesemise viht ja seep pandi surnule kirstu kaasa (Raadla 1939: 21; Reimann 1915: 143). Jüri Viikbergi ja Lembit Vaba andmetel toimisid vähemalt Minussiinski piirkonna eestlased samuti - surnupesu nuustik ja seep ning kuivatusrätt pandi lahkunule kirstu padja alla (Viikberg \& Vaba 1984: 152). Minu küsitlus Siberis andis siinkohal erineva tulemuse - surnuseepi, mõnikord ka lappi hoiti hoolikalt alal, neid kasutati raviotstarbel:

Ku sureb, siis võta see seebitükk ehk see kalts, kellega pestasse. Ja pia see kalts kogu aeg endal ühes. Teinekord hammad valutavad kõvasti või kuskilt on kõvasti paistes, pane piale ehk hõeru selle seebitükiga, nii annab kohe järele. Paned selle kaltsu niimoodi hammaste piale ja jääb hammavalu järele. [---] Kui miski on valus, hõerud kuivalt selle seebitükiga (CD-0007 (12) < Vana-Viru k - Anu Korb < naine, s 1924 (1997)). 
Tegelikult on surnuseep ravivahendina üldtuntud Eestimaalgi (Eisen 1920: 164; Manninen 1924: 12; Kõivupuu 2000: 20-22). Surnuseepi võis mujalgi tarvis minna, näiteks teati mõnel pool Siberis, et selle abil võib kohtus võidu saada:

Kunsti tettäss: tuu siip, kellega surnut mõset, paned endale sinna pääle, vasta ihu, siss saad kohtus õigust. Ol'l ka õigus. Samagonni tegemise iist anti trahvi õnne, ei pantu kinni. Siip hoidis kohtu iist (EFA I 17, 16 (10) < Tara raj, Jurjevka k Anu Korb < mees, s 1944 (1996)).

Surnuseebist otsiti Siberis abi ka kurja joodiku mehe vastu:

Kellel on mies paha, kisub, siis selle surnupesusiebiga las ta peseb kääd ära, siss see käsi änamb ei tõuse lüöma (CD-0011 (61) < Kovaljovo k - Anu Korb < naine, s 1916 (1997)).

Üksikuid samasisulisi teateid leidub ka Jakob Hurda rahvaluulekogus:

Seebitükk, millega surnut sai pestud, peab alles hoitama. Kui naisel tige mees on, kes teda alati peksab, siis pesku naine nimetatud seebitükiga mehe särkisid, ehk siis mees küll tapleb ja riidleb, aga ometi ei või ta oma kätt naise löömiseks tarvitada (H II 57, 536 (31) < Järva-Jaani khk - Julius Aleksander Rehberg (Reepärg) (1896)).

Nõrgal surnul köideti käed-jalad kinni, et need koos püsiksid. Enne matmist tuli need kindlasti lahti võtta. Paelad võidi jätta kirstu, kuid alati seda ei tehtud. Neidki kasutati maagilisel otstarbel, Siberis näiteks kakleja mehe taltsutamiseks:

Vaata, kui surnu on nõrk, seotakse jalgu kinni nii, et oleks kuos. Ja kääd mõnedel seotakse. Vot see pael tarvis korjata ära, kellega kinni on seotud. Ja kelle mies juob ja kisub, selle paelaga, kui ta on juonud, siduda käed kinni-ei hakka kisku$m a$ (CD-0010 (55) < Kovaljovo k - Anu Korb < naine, s 1905 (1997)).

Riiakad joodikud mehed on mitmel pool Siberis probleemiks ja seetõttu on arhailised võtted ka säilinud. 
Anu Korb

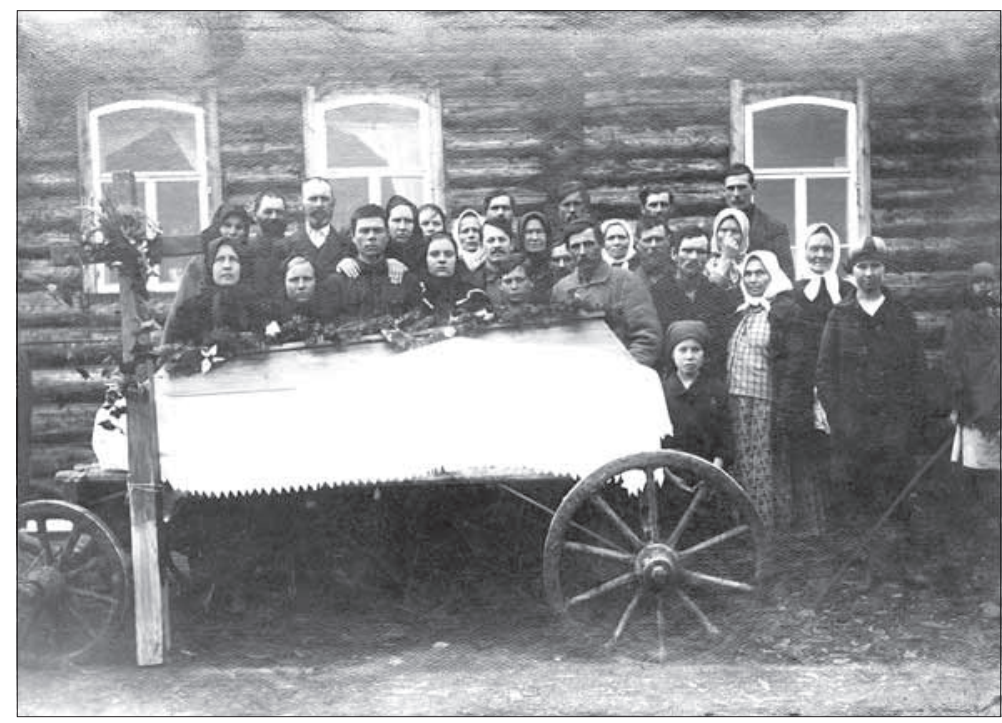

Foto 2. Reinholdi perenaise matused Koltsovo külas 1929. aasta paiku. Foto saadud Voldemar Kiivitilt.

Suririided on vanematel inimestel tavaliselt nii Kodu-Eestis kui ka Siberis varakult valmis ning selga tuleb panna just lahkunu enda poolt valitud rõivad. Noore inimese äkilise surma korral riietatakse ta lähedaste maitse järgi. Surirõivaste värv pole Siberi eestlastel ette määratud. Meestel on surirõivaks sageli tume ülikond, naiste kleit või pluus võib olla mis tahes värvi. Mõnes paigas, näiteks Rõžkovos, eelistatakse heledamaid riideid. Valge ehk hele surirõivana ongi ilmselt varasem kui tume riietus (vt nt Hupel 1777: 155). Mõnel pool Siberis mäletati, et varem on maetud surnu laulatusriietes (Korb 1996: 27), mida on muiste eelistanud surirõivastena paljud rahvad (Paulaharju 1924: 81). Naissurnule pandi enamasti rätik pähe, nurgad vaheliti, sõlmede tegemine oli siberlastel keelatud, nagu varem nii Eestis kui ka mujal (vt ka Mikkor 2001: 111). Siberi eestlastelt on teateid ka surnud abielunaisele tanu pähepanemisest:

Kui vanamutid surevad, siis tehakse tanud... Kui Ruudi ema suri, siis tehti roosast lindist, pandi pähe (RKM II 449, 330 (20) < Kaseküla k - Kadri Peebo < naine, s 1934 (1992)). 
Kodumaal taandus see tava juba sadakond aastat tagasi - 20. sajandi alguses.

Aliise Moora väitel pandi surnule esemeid kaasa Eestis veel 19. sajandil (Moora 1956: 33-34), kuid tegelikult pole esemete kaasapanek tänini täielikult kadunud, näiteks Võrumaa traditsioonist on teada, et surnule pannakse nüüdki kirstu kaasa nii vaimulikke raamatuid, laululehti, lemmikesemeid, elusaid lilli, metallraha kui ka viinapudel (Torp-Kõivupuu 2003: 130). Siberi eestlaste hauapanused on märksa tagasihoidlikumad. Samuti tuleb märkida, et Võrumaalt väljarännanute hauapanused ei erine teistest piirkondadest pärit rahvuskaaslaste omadest. Kõige sagedamini pannakse lahkunu soovil kirstu piibel või lauluraamat. Jumalasõnaraamatute kirstu panekut põhjendatakse sageli sellega, et nooremad pereliikmed eestikeelset jumalasõna ei vaja, sest nad ei oska eesti keeles lugeda, kuid püha raamatut ei taheta niisama vedelema jätta. On ka vastupidiseid arvamusi - jumalasõna ei tohi kirstu panna, sest see peab jääma elavate tarvitada. Teeraha või kohaostmise raha surnule kaasapanekut seostavad Siberi eestlased eelkõige sakslastega, mõnikord ka venelastega. Tegelikult on sama tava tuntud laiemalt, ka näiteks grusiinlastel, armeenlastel (Mikkor 1992: 170) ning paiguti Eestimaalgi (Torp-Kõivupuu 2003: 130-131).

Venemaal eksponeeritakse üldse rohkem eluajal saadud ordeneid-medaleid kui Kodu-Eestis. Sõja- ja tööveteranidele panevad Siberi eestlased mõnikord nende autasud kirstu kaasa.

\section{Matjad Siberi külades}

Põhierinevus Siberi ja kodueestlaste matusekombestikus johtub matusetalituse läbiviijast. Eestis jääb selle leidmine tänapäeval ilmaliku matuse korral matusebüroo hooleks, koguduseliikmeid matab enamasti kohalik pastor. Siberi eestlastel pole tänapäeval kirikuid-palvemaju ega vaimulikkegi, üksnes Ülem-Suetukis taastati soomlaste abiga kirik, kuid õpetaja käib kord aastas Eestimaalt. Matmisega on külaelanikud pidanud juba ligi 80 aastat ise hakkama saama. Siberi eestlaste külakogukond peab veel tänapäevalgi jumalasõnata matmist häbiväärseks. Naabrite ilmalikku matust halvustatakse sõnadega: aeti nagu loom auku. Siberi eestlastele on luteri usk üks identiteedimääratlustest, seega siiani väga 
Anu Korb

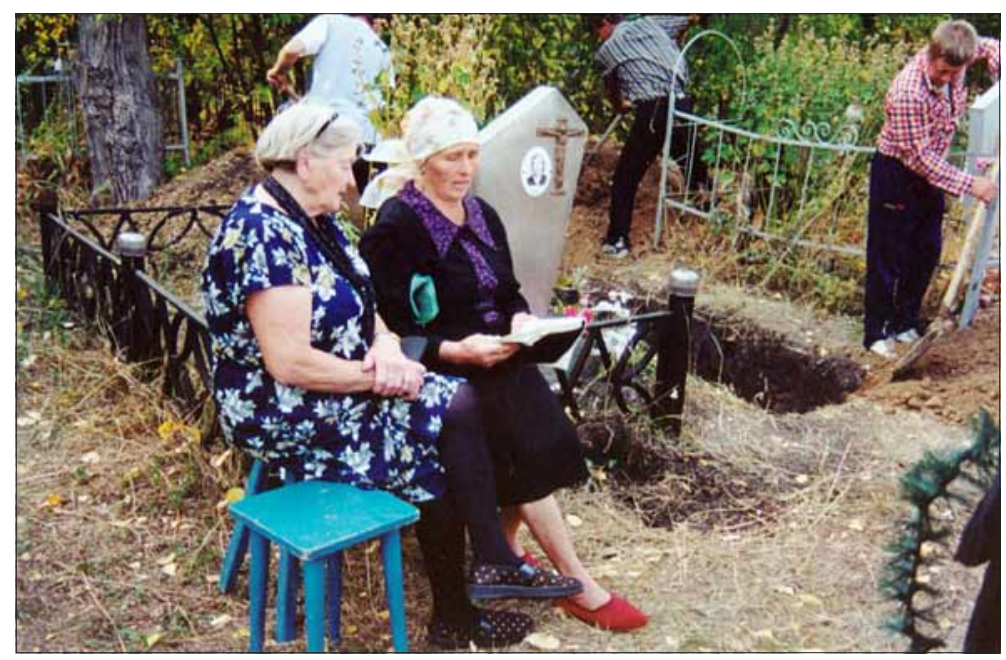

Foto 3. Jaan Rebase matused Zolotaja Niva külakalmistul. Haua kinniajamisel laulavad Valentina Täär ja matja Rosalie Taits. Anu Korbi foto 2000 (ERA, of 3337).

oluline. Usuelu kiratsemist on aga kurdetud asunduste algusest peale (vt nt Postimees 1899, nr 196). Pärast vaimulike (enamasti mehed) represseerimist 1920.-1930. aastatel läks kiriklike talitluste läbiviimine külamatjate - üldjuhul naiste - kätte (Jürgenson 2000: 42-44). Sama nähtus on levinud ka mõnede teiste Venemaa rahvaste juures (vt nt Kallatsa 1994: 26-27). Põhjuseks oli see, et väljasaatmine otseselt naisi ei ohustanud. 1936.-1938. aastate repressioonid ei jätnud ühtki asundust puutumata, mitmes Siberi eesti külas vangistati peaaegu kõik täiskasvanud mehed. Järgnes Teine maailmasõda, mis viis vähesedki küladesse allesjäänud mehed rindele. Pärast sõda küll meeste osa külas suurenes, kuid nad jäid ikkagi vähemusse. Ajapikku harjuti Siberi eesti külades naiste juhtiva rolliga. Kuna naised on loomult alalhoidlikumad ja rohkem traditsioonides kinni ning kogukonna kombetalitused tuli toimetada, saidki naised riituste läbiviijateks. Külakogukond aktsepteerib traditsiooni niisugusena, nagu see on kujunenud, oluliseks peetakse jumalasõnaga matmist.

Ristijateks-matjateks ei olnud ainult vanad naised, mõned alustasid oma tegevust juba enne 40. eluaastat: 
Oh ma enam ei mäleta, millal ma juba ristisin. Esimese lapse, näe, ristisin, ja nü̈̈d matsin ta ära ka, 42 aastat tagasi. 42aastane oli (DV 130 < Ülem-Suetuki k - Astrid Tuisk, Andres Korjus < naine, s 1920 (2000)).

Tundub, et ristimisse suhtusid võimuesindajad taunivamalt kui matustel jumalasõna lugemisse. Siiski on omajagu üllatav, et jumalasõnaga matmine kuulub külakogukonna matusekombestikku veel 21. sajandi künniselgi. Varem oli suuremates eesti külades isegi mitu matjat:

A enne olli vot Ida, Hõimu Ida. Vat see, kes pildi peal oli. Tema mattis ja siss oli veel, Hõimu Liide oli. No see suri veel varem ära. Vot see mattis. Ja veel ol'l üks Skilleri Jaana, need olid kõik vanemad ja nad surid juba kõik. [---] Meil meesterahvit ei olnd. Naised kõik matsid (CD-0492 (3) < Zolotaja Niva k - Anu Korb < naine, s 1928 (2000)).

Linde Alma, tuu om meil nüid pap'p. [---] Ku keski sures, siss jällekine [surnut] valvma ja kõik. Temä ütles siss sõnad keik säält. Tel on pühä raamatud. Ta ütles sõna ette, siss laulva jälle takant tõse vanainemese (FA DAT 53 (44) < Lillikülä k Anu Korb < naised, s 1921 ja 1954 (1996)).

Matjaid küsitledes huvitusin ka sellest, kuidas ja kes matjaks võib saada. Selgus, et kel tahtmist, võis ameti ise selgeks õppida:

Aga kas keegi siis õpetas või?

- Ei, hakkasin ise kodu kah neid raamatuid lugema. [---] 1938. aastal isa viidi, võeti ära piiblid ja. No siis mul nii himu oli neid lugeda (DV 130 < Ülem-Suetuki k - Astrid Tuisk, Andres Korjus < naine, s 1920 (2000)).

Üsna sageli päriti amet esivanemalt:

Kerstu panemisel tuleb lugeda ja kui välla saadad surnu, tuleb lugeda ja surnuaias veel kolmas kord. Mina olen pallu neid lugend. Enne mu mamma Anna Lillo, sündinud Uibo, luges. 45 aastat vist olin, kui mamma suri. 44-aastaselt ma hakkasin käima matmas ja ristimas (EFA II 2, 214 (18) < Ivanovka $\mathrm{k}$ - Anu Korb < naine, s 1913 (1995)). 
Anu Korb

Mõnikord ei tahtnud matja järeltulija ametit jätkata, kuid külakogukonna survele ja teadmisele, et jumalasõnata matmine tähendab kogukonna normide rikkumist, ei ole suudetud vastu seista:

Vot sellepärast ma hakkasin matma, meie külast oli see meie piirinaine. ${ }^{3}$ Meie elasimi Nikolajevkas, need olid Nikolajevkast ja me olime Nikolajevkast. Ja tema suri ära noorelt. Ja see tulid kokku kõik tema õed. Noja kedagi ei ole, kes teda matab. Nemad tulid siia nutuga. Ära matja sõitis ära Eesti ja kedagi ei olnd. No minu isa mattis, nad tiavad, et minu isa mattis, et võib. Tule ja tule. Mina ütlesin, mina ei oska ja raamatut ka ei olnud. Kust nad leidsid raamatu. Kuidas oskad. Kuidas me veeme kui looma hauda. Noja midagi, mees ütles ka, no kui oskad, siis mine. Noja mina läksin. Mina läksin, matsin, kudas ma oskasin. Raamatus, mis raamatusse kirjutud, seda ma lugesin. Noja matsin siis selle ära ja nüid peale selle, kes sureb, jällegi piad mina mineme. Üles öelda tuleb, et ei ole illus. Inimene tuleb nutuga, palub, tule ja tule. No ei ja tuleb jälle minna noh. [---] Üldse ei meeldi mulle see matmine, noh no kui inimene nõuab, siis peab, peab minema. [---] Mina olin laps ja mina mäletan, kui minu isa mattis. Matuse pial tema luges, kõik seisid ja kuulasid ja mina, laps, kuulasin ja mina panin meelde nied lauluviied, mis isa laulis. Ja nüid lauluviiesid tian ma pallu, jumalasõna lauluviiesid. Noja see matmisekombe kah, mul on mieles (CD-0116 (18) < Oravaküla $\mathrm{k}<$ Nikolajevka k - Anu Korb < naine, s 1926 (1998)).

Mõnikord valib inimene, kes tunneb surma lähenemist, ise endale külarahva hulgast matja, hoolimata sellest, et väljavalitu pole varem selles ametis olnud:

Mul ol'l üks vanaema, kas tead, see Leonora ema, see kogu aeg ütles mulle, et sina mind matad. A ma ütlesin, mina ei oska. Ja siis ta kuskilt sai selle raamatu ja siss luges minule ette, a mina ei oskand neid lugeda. Vanas kirjas neid ei oska lugeda. Ta siis ütles mulle ette, a mina siss kirjutasin.

"Noja ku ma ära suren, siss sa matad minnu."

Noja suri ära ja matsin. Siis ütlesid: "Oi, sinul läks päris hästi.” Ja pääle selle mina ütlesin küll, vaadake, et te kellegile ei ütle, et mina noh matsin. A kost, kui juba ära matad, kellel see suu kinni on. Ja nii läkski. [---] Üks kutsub, teine kutsub, 
eestlase, no kôik on nad tuttavad, kudas sa eestlasel... Ütlesin küll, et oi ma ei lähe, et ma ei oska veel. No es jätava järele, ja nii, kui eestlane sureb, nii jälle mind kutsutakse (CD-0492 (2)

< Zolotaja Niva k - Anu Korb < naine, s 1928 (2000)).

Matjad on oma vastutusrikkast rollist teadlikud ning püüavad oma teadmisi jõudumööda täiendada. Üheks probleemiks on kiriklike talituste raamatute nappus tänapäeva külades. Kindlasti oligi neid raamatuid algusest peale vähem kui piibleid ja lauluraamatuid. Repressiooniaastatel 1936-1938 hävitati põhiosa eestikeelsest kirjandusest, jumalasõna julgesid alal hoida vaid vähesed, sel juhul peideti need hoolikalt. Niisiis on üksikud säilinud raamatud vägagi hinnas ning vajadusel käiakse neid laenamas:

Tiigi Liide luges matustel. Nüid mõnikord mina ka loen. Voormani Evaldi ema lugemise raamat. Sealt võtavad ja viivad jälle tagasi (RKM II 466, 502/3 (2) < Vambola k - Anu Korb < naine, s $1938(1994))$.

Minulgi on palutud külla saata ristimis- ja matmissõnu. Kõige sagedamini on Siberi eestlastest matjatel oma käsikirjalised kladed, kus vajalikud tekstid ja laulud sees. Igaüks on need oma oskuste kohaselt kirja pannud. Venekeelse koolihariduse saanud siberlastele valmistab eesti keeles kirjutamine üldjuhul raskusi, tekstid on sageli pandud kirja vigaselt ja puudulikult.

Kuna matuserituaali juurde kuuluvad vastavad laulud, tuleb matjal tseremoonia läbiviimiseks ka laulusõnad hankida ja laulud selgeks õppida. Tavaliselt kopeeritakse matuselaulud kellegi käsikirjalisest kladest:

A laulud kirjutasi ma Hõimu Ida käest. Tema iga kord surnu man laulsid ja me aitasime ka laulda. A ei oska laulda. Siss kirjutasin üles, siss õppisime (CD-0492 (4) < Zolotaja Niva kAnu Korb < naine, s 1928 (2000)).

Matja ülesanne on küll rituaali juurde sobivad laulud välja valida, kuid kaasa laulavad kõik oskajad:

Matuksel Olga Andrejevna aitab ka laulda. [---] Ma ütlen sõnad ette, need jumalasõnalaulud on ju nii lihtsad. [---] Laali Ida, tema ka laulis. Ja viel Tompus, Elfriede... [---] Vambola 
Anu Korb

inimesed laulsivad [matustel]. Me laulsime kõik (FA DAT 8 (14) < Kaseküla k - Anu Korb, Aado Lintrop < naine, s 1913 (1993)).

Matustel laulmist peavad Siberi eestlased just oma matusekombestikku kuuluvaks:

Venelastel ju ei lauleta matustel. [Üldistus tehakse oma naabrust silmas pidades, tegelikult võidakse vene matustel laulda küll - A. K.] Kui me, eestlased, jääme sinna, siis ikka laulime: "Oh puhka sa rahul...", "Ma suren siin lillede keskel...", "Kas ema südant...", "Üks ainus kord siin ilmas...". Need olid vanemate käest, nii kudas meelde on jäänud. Vanasti kogu tee laulime, kui surnu viidi hobusega, ja ühtki laulu ei korranud (RKM II 466, 309 (8) < Mariinski raj, Jurjevka k - Anu Korb < naine, s 1929 (1994)).

Venelaste matustel kuuldud surnuitku eestlased lauluna ei käsita, pigem tekitab see nendes võõrastust:

Võetakse see nutunaine, see rüögib nagu metsloom. Maksetakse välla seuke kisakõri (RKM II 459, 90 (67) < Kaseküla kAnu Korb < naine, s 1919 (1993)).

Siberi eestlaste matuselauludest on vaid üksikud seotud konkreetse kombetäitmisega, näiteks surnu väljaviimisel lauldakse "Las ma lähen...", surnu haudalaskmisel "Mu rahukamber valmis...", kuid põhiosa lauludest võis laulda vabalt valitud järjekorras nii surnu valvamisel kui ka matustel. Laule võis vastavalt olukorrale ka kohandada. Eriti palju on lauldud endiste ansambli- või koorilaulujuhtide matustel. Külades, kus tänaseks on laulutraditsioon hääbunud, võidakse surnu juures siiski veel laulda. Repertuaar erineb külati üsna oluliselt, erinev on ka vaimulike ja ilmalike laulude vahekord (vt Korb 1998: 153). Matustel kasutatakse ka Eestimaalt saadud laululehti või neilt mahakirjutatud laule. Näiteks Zolotaja Niva küla matja käsikirjalises ristimis- ja matmiskaustikus leidus kokku 34 laulu, neist kaks venekeelsed, 32 eestikeelsest laulust olid pooled kopeeritud Eestimaa laululehtedelt.

Varem, kui mitmes Siberi eesti külas oli oma puhkpilliorkester, mängiti ka matustel. Nüüd võivad puhkpilliorkestri saatel maetud saada vaid Ülem-Suetuki elanikud, teistes külades oma orkestrit lihtsalt pole. 
Kõigele vaatamata napib Siberi eestlastel tänapäeval matusetalituse läbiviijaid ning traditsiooni järjepidevus on katkemas ja muutumas. Mõni matja on järglase välja valinud lootuses, et ta siis ka ise traditsioonikohaselt maetud saab:

No ma ütelsin omale ristitütrele Liljale: "Ku mina ära suren, sina matad mind. Ma jätan omad raamatud kõik sinule." A kuhu ta pääseb, ta piab matma mind (CD-0492 (3) < Zolotaja Niva k - Anu Korb < naine, s 1928 (2000)).

Mõni kõrges eas matja on püüdnud oma teadmisi laiemaltki levitada:

Ma kirjutasin neid vihikutesse ringi. Ja siis ma niipalju kui Pulanisse $e^{4}$ andsin nüid ja kel ma olen ikka andand neid, et hakake lugema. Pulanis ma käisin matmas, ikka siis andsin sinna, Saare Juhannale andsin ühe enda kirjutud. Matke, nõnna laulge ise ja matke (DV $130<$ Ülem-Suetuki k - Astrid Tuisk, Andres Korjus < naine, s 1920 (2000)).

Olemasolevaid matjaid võidakse külas kritiseerida, et see või teine ei loe õigesti, kuigi vaevalt et põhiosa küsitletutest oskakski öelda, missugune lugemine on õige.

Mõnedki külaelanikud muretsesid, kas neile enam matjat leidubki. Esmatähtis on kombe säilimine, mille kõrval rahvuslik ja isegi konfessionaalne taanduvad. Kuna traditsioon nõuab jumalasõnaga matmist, võidakse häda korral kutsuda luteriusuline naaber, kes loeb surnule enamasti vene keeles:

Meie rahvas nü̈̈d kutsub [matustele] sakslasi lugema. Neil on meesterahvad lugejad. Lugeja tuleb, ta loeb vene keeli meile (EFA I 19, 5 (8) < Tsvetnopolje $\mathrm{k}$ - Anu Korb < naine, s 1927 (1997)).

Samuti on mõningaid Vana-Viru küla eestlasi matnud viimastel aastatel lätlane. Tegelikult pole sõnadest arusaamine ega isegi matja usuline kuuluvus matustel viibijatele esmatähtis. Näiteks on eestlast, kes loeb jumalasõna luteri traditsioone järgides ja eesti keeles, vahetevahel ka vene külla õigeusulist matma kutsutud. Eestlastegi matustel on tänapäeval paratamatult sugulasi-tuttavaid, kes eesti keelt ei mõista. 
Anu Korb

\section{Surnu hoidmine, abinõud surnu halvaksminemise vältimiseks, valvamine ja vaatamas käimine}

Varasemal ajal viisid nii kodueestlased kui ka Kaukaasia eestlased surnu kõrvalhoonesse, tänapäeval hoiavad kaukaaslased surnut enamasti elutoas (Mikkor 1994: 1253). Ka Siberi eestlastel on surnu kodumajas, tavaliselt kütmata elutoas. Külmkambrite kasutamise võimalused külaelanikel tavaliselt puuduvad või on need liialt kallid, puudub ka vastav traditsioon. Eestimaal kohtab surnu kodushoidmist järjest vähem. Viimastel aastatel on Eestis enam levinud tuhastamine. Surnu ärasaatmine krematooriumist muudab iseenesest oluliselt kogu kombestikku. Ka laibamatuse korral saadetakse järjest sagedamini lahkunu ära ametiruumidest või kabelist, mitte kodunt. Seega kaovad mõned vanad kombestikuelemendid nende muutuste mõjul iseenesest.

Siberi külakogukonnas pole laibamatusele alternatiivi ja surnu saadetakse ära tingimata kodunt. Kui keegi kogukonna liikmetest surebki rajoonikeskuse haiglas, tuuakse ta sealt koju ning edasi toimitakse sarnaselt kodus surnuga. Surnut hoitakse eluruumides, kõrvalhoones hoidmise eest lausa hoiatatakse:

Kohe sa viid? Vii aita, roti sööva ära. Hiire, suured võhlud. ${ }^{\mathbf{5}}$ Jah. Võhlud söövad ära. Sest naabrikülän olli üks miis puus üles, see Veedemi Albert ütel, ja nema võtiva maha. Ja jätsiva selle aita. Jätiva sinna aita maha ja nii kaua, kui sääl miilitset otsiva ja joba võhlud oliva nina pääst ja mokad ära söönuva ja püksest pissiotsa (Disk 11 < Tartu l < Koltsovo k - Anu Korb < naine, s 1929 ja mees, s 1928 (2004)).

Käibel on ka nn hoiatusjutud:

Surnu peab toas olema, ei tohe välla viia. Ma tean, meil oll üks. Ee Lõksi Katre. Ja tema suri ka suvõl, väega sääne palav ilm oli, ja toodi haiglast kodu. Ta läks nii paistes, lõhn oli juures, ja lapsed, nad tuppa ei viindki. Noja oli vällas nii, toa ääres või juures seal. Ja tiad, ta käis kogu aeg nutma kodu, mispärast te tuppa mind es vii. Need lapsed kohe kartsid kodu olla, magada. Ütles: "Kohe nutab ja, ja kuuled õka, et ema nutab: "Mispärast?"” Ja unes näitas: "Mispärast te mind jätsi- 
te välla?" (CD-0492 (7) < Zolotaja Niva k - Anu Korb < naine, s 1928(2000)).

Suurt tähelepanu pööratakse külas surnu halvaksminemise vältimisele. Selleks kasutatakse nii esivanematelt kui ka naabritelt õpitut. Traadiga maaühendus on üks tavalisemaid, harvemini kasutatakse teisi raudesemeid (näiteks kirves veepanges, nõel huulte vahele). Mitmel pool on tuntud ka näiteks kanamunade panemine kirstu või lautsi alla või kohe surnu juurde. Abi võis olla ka liivast - õhuke kord liiva kotiga lautsi alla - või maast:

Surnu mätaste peale panime ja ta ei läind üldse pahaks. Rohu pool ülesse ja siis pannakse riie. Suri laupäeval, a me nellapäeval matsime ja oli täitsa ilus veel (EFA II 2, 214 (20) < Ivanovka k - Anu Korb < naine, s 1913 (1995)).

Surnu valvamine on Siberi eestlastel püsinud suhteliselt elujõulisemana kui Kodu-Eestis (Võrumaa vastava kombe kohta vt TorpKõivupuu 2003: 132 jj), mitmes piirkonnas on tava üldlevinud veel tänapäevalgi. Valvama kedagi ei kutsuta, igaüks tuleb, millal tahab. Surnu valvamise juures võidakse pakkuda viina ja suupisteid, kuid see pole kohustuslik. Lauldakse surma- ja matuselaule ning vesteldakse isekeskis:

Näki Liisi loeb, Erminna ka võib lugeda. [---] Liisi loeb heasti ja Erminna ka loeb heasti. Inimene sureb ära, siis nad laulavad ja loevad jumalasõna. No õhta tulevad nõnnaviisi ligemised. Ise tulevad, istuvad ja laulavad ja rä̈̈givad ja... [---] On neid talusi kah, kus pandasse söök lauale, valatasse igaühele pits: kis tahab juvva, joob, ja vabše ${ }^{6}$ piaaegu kõik joovad ära selle ja lähvad ära. A on neid talusid muidugi, kus midagi ei anta (CD0011 (57) < Kovaljovo k - Anu Korb < naine, s 1916 (1997)).

Ilmselt pole surnuvalvamised olnud alati surmtõsised ettevõtmised, surnuvalvamise juures mängimise ja rõõmsate laulude laulmise kohta on teateid mitmetelt rahvastelt, mingil määral ka eestlastelt (vt nt Lang 2004: 85-86). Järgnev Siberist saadud teade - vingerpuss uinunud kaaslasele - viitab samuti meelelahutuslikule:

Valvama minnakse [surnut]. Teinekord on puusärkis, teinekord ei ole. Omad läksid kohe ise. Ö̈̈ otsa istusivad. Kes 
Anu Korb

magama jäivad, õmmeldi kinni. Alusjupkaga õmmeldi mind ka sängi külge. Ärkasin, pime oli. Ma ehmatasin ära, et ei saa liikuma. Kui tõmbasin ropsuga, riidetükk jäi sinna maha (EFA II 2, 215 (21) < Ivanovka k - Anu Korb < naine, s 1913 (1995)).

Tänapäeval on mõnel pool Siberi eestlastelgi analoogiliselt kodueestlastega (vt Torp-Kõivupuu 2003: 133) surnu valvamine asendunud surnu vaatamas käimisega:

[Surnut valvamas] nüid enamp ei käia. [---] Eestlastel om iks, käiva vanainemise sääl laulman õdagu ja istusse sääl iks paar' tunni tolle surnu man (FA DAT 48 (131) < Jegorovka $\mathrm{k}<$ Tara raj, Jurjevka k - Anu Korb < naine, s 1913 (1996)).

\section{Puusärk, kirstupanemine}

Siberlaste kirstud tehakse tavaliselt kodu- või naaberkülas. Varasemad kirstud olnud kvaliteetsemad, nt Koltsovo külas tehtud 20. sajandi esimesel poolel seedripuust, jämedast värvimata lauast kirstud. Laudkirstud on olnud Eestis kasutusel juba 19. sajandi algupoolel. Kirstulauad olnud varem sageli eluajal valmis muretsetud nii Siberi külakogukonnas kui ka Kodu-Eesti maapiirkondades. Tänapäeval on Siberis korralik puitmaterjal defitsiit, eriti stepialadel. Nüüd on puusärgid enamasti riidega üle löödud, nii pole puidu kvaliteet esmatähtis. Riie võidi kirstule panna ka alles kodus, näiteks pitsiga kaunistatud atlassiid, kirstukaanele võidi kleepida või õmmelda valge rist. Tänapäeval saab osta ka riidega ülelöödud valmis kirste. Kuna kirsturiide valik on Siberis enam kui kasin (tavaliselt saab valida musta ja punase kanga vahel), on kirstud üsna ühetaolised. Valget risti kirstukaanel märkasin Rõžkovo külas lätlanna matusel. Sealsed eestlased pidasid seda läti kombeks.

Kirstupanek on siberlastel suhteliselt vaikne toiming, millel osalevad vaid lähimad omaksed, enamasti loetakse sealjuures ka jumalasõna ja pühitsetakse kirst. Kirstupanek võib toimuda niipea, kui kirst valmis. Mõnikord jäetakse kirstupanek vahetult matuseeelsele ajale ning sel juhul osalevad sellel kõik matuselised.

Siberi eestlaste kirstudel pole käepidemeid, kirstu alla on löödud paar liistu, et kirstu käterättidega (vahel ka köitega) kanda ja 
hauda lasta. Kuna korralikku köit on tänapäeval raskem hankida kui käterätiriiet, kasutatakse surnukandmiseks nüüd pigem käterätte. Siberlase kirstukaas ei käi kruvidega kinni nagu tänapäeva Kodu-Eestis. Kirstukaas lüüakse suurte naeltega kinni surnuaias, varem toimiti nii ka Eestimaal (vt Raadla 1939: 43-44). Kirstu naelutamine oli surnuaiavaikuses üsna võigas heli.

\section{Matuste aeg, matustele minek}

19. sajandil määrati matmisaeg seadusega kindlaks - enne kolme päeva ei tohtinud matta (vt nt Raadla 1939: 38). Siberi eestlastel on tavaks matta surnu kolmandal päeval, nädalapäev tavaliselt tähtsust ei oma. Siberi venelased matavad surnu kohe surmajärgsel päeval. Vaid erandjuhul võidakse ka Siberi eestlane juba teisel päeval matta, näiteks kui surnu kipub halvaks minema. Kolmandal päeval matmist põhjendatakse võimaliku varjusurmaga - selleks ajaks on kindel, et inimene on tõepoolest surnud. Vaid siis, kui matustele oodatakse mõnd kaugel elavat lähisugulast, võib matus toimuda ka veidi hiljem. Alati aga mujal elavad lähisugulased matustele sõita ei jõuagi, põhjuseks nii pikk teekond kui ka rahamured. Eestis kulub matuste ettevalmistamiseks tavaliselt rohkem aega (neli-viis päeva), sageli maetakse surnu just nädalavahetusel, kui omastel on lihtsam kokku tulla.

Siberi eestlased rõhutavad, et neil, vastupidiselt venelastele, kutsutakse matustele ning kutsumata sinna ei minda. Kogu külarahvas kutsutakse nüüd matustele harva, see tuleb kõne alla vaid väikestes külades. Tavaliselt on nooremate inimeste matused rahvarohkemad. Eestlased lausa halvustavad venelaste jt kutsumata matustele minekut. Ka Kaukaasia eestlastel oli tavaks matustele kutsumine, teistel kaukaaslastel aga sinna kutsumata minemine (Mikkor 1992: 169). Endistes Siberi eesti külades, nüüd suurtes ja paljurahvuselistes, siiski varasemad kombed enam ei kehti:

Ennemb omad sugulased kutsuti matustele, a nüid tulevad surnuajast kõik, kutsutakse kohe. [---] Ennemb saadeti ringkiri: minule toodi, mina viisin piiriperemehele ${ }^{8}$ ja tema edasi, et palume tulla matustele. See oli meie eesti külas, a nüid ei teagi, kui teisel uulitsal [keegi] ära sureb (EFA I 19, 20 (57) < Tsvetnopolje k - Anu Korb < naine, s 1923 (1997)). 


\section{Anu Korb}

Kui Kaukaasia ja Eestimaa eestlased toovad matustele kaasa lilli ja pärgi, siis Siberi eestlastest matuselistel on elavaid lilli harva. Siberi karmis kliimas on looduses lilleaeg lühike, hauakaunistusteks on valdavalt kunstpärjad. Suvekuudel võidakse Siberiski matustele võtta kaasa koduaia lilli, kuid võrreldes Kodu-Eesti matustel nähtuga on siberlastel lilli märksa vähem.

\section{Haud, hauakaevajad}

Haud kaevatakse tavaliselt matusepäeval. Siberi eestlased järgivad tänapäeval rangelt tava, et hauakaevajad ei tohi olla omaste hulgast, nt lahkunu pojad. Varasemas Siberi ja ka Eestimaa kombestikus olid hauakaevajad küll sugulased, tänapäeval tavaliselt võõrad palgalised. Hauakaevajate söötmine-jootmine on tuntud nii Kodu-Eesti, Kaukaasia eestlaste kui ka Siberi eestlaste traditsioonis. Hauakaevajatele käterättide kinkimise on Siberi eestlased nüüdseks venelastest naabritelt üle võtnud:

Nü̈̈d on see venelaste mood võetud, et käsirätt, ${ }^{9}$ millega surnut viias, antakse hauakaevajale. Kaks pikka käsirätti on, nellani viivad. Mitu meetert ta on, ma ei teagi, meil lapsed ostsivad. Siis lõigutasse pärast seda rättija seotas igale hauakaevajale käe külge (EFA I 19, 20 (59) < Tsvetnopolje k - Anu Korb < naine, s 1923 (1997)).

Varem antud igale hauakaevajale paar kindaid, nüüd on tasuks ka raha.

\section{Matuserong ja -talitus kalmistul}

Siberi eestlastel algab surnu kodunt ärasaatmine lõuna paiku, ajavahemikus kella kaheteistkümnest kaheni. Konkreetses külas alustatakse matusetalitust alati ühel ja samal kellaajal. Harva tuli ette olukorda, kus matusemajas oli veel ristimata väikelaps. Sel juhul pidi järgima vastavaid reegleid:

Vat oligi, vanaema suri ära, a Inga oli ristimata. [---] Ristisid enne lapse ära ja siis alles hakkasid surnule laulma. [---] Enne 
ristiti laps, siis alles surnu viidi ära toast, a enne ei saand viia (CD-0020 (58) < Vana-Viru k - Astrid Tuisk, Aivar Jürgenson $<$ naine, s 1920 (1997)).

Surnu viiakse alati välja, jalad ees.

Varasemast ajast on tuntud surnu kalmistule viimine hobuvankril või inimjõul:

Ennemb oli küll sääne muud, viidi kässi pääl. Kolm käterätikut, nagu kirstu alt too ots tuleb, paned ümbre kaala ja kogu aeg nii viid. Kuus meest peab olema (EFA II 2, 7 (19) < Zolotaja Niva k - Anu Korb < naine, s 1928 (1995)).

Tänapäeval pannakse sageli surnu väikesele veoautole, tagumine luuk hoitakse lahti. Puusärk viiakse lahtiselt, kaas kõrval. Põhjendatakse, et surnu näeb veel viimast korda oma koduküla. Lahkunu juures istuvad lähemad omaksed ja matja. Matuselised sammuvad tavaliselt jalgsi, vaid vanemaid inimesi võidakse autodega kohale viia. Siberi eestlastel kehtib range keeld - sugulased puusärki kanda ei tohi. Eestimaa eestlaste puhul võib keeld kehtida vaid poegadele, lapselapsed kannavad tänapäeval vanaisa-vanaema kirstu üsna sageli. Ristikandja on Siberi eestlastel tavaliselt ristipoeg. Eestist on vaid mõned sellekohased teated.

Lillede või okste viskamine matuserongi teele, tuntud mitmetel rahvastel ja alates 1950. aastatest ka Kaukaasia eestlastel (Mikkor 1992: 174), või eelnev kuuseokste mahapuistamine (Kodu-Eestis üsna tavaline) pole Siberi eestlastel üldiselt kombeks. Mõnikord on Siberis suvel surnu teed siiski metsalillede või roheliste okstega tähistatud. Stepipiirkonnas, kus kuuski ei kasva ja puid on üldse vähe, ei saakski oksi kasutada. Kombeks pole ka ise elavatest okstestlilledest pärgi teha, tänapäeval kasutatakse valdavalt ostetud kunstpärgi, neid nimetatakse kroonideks.

Surnuaia väravas tõstetakse surnu kodunt kaasavõetud pingile või taburettidele ning vajadusel kohendatakse teda. Seejärel liigub matuserongkäik hauani: ees kirstukaas, järel neli meest kirstuga ning matuselised. Nagu eespool mainitud, kantakse kirstu käterätikutega. Pärast lõigutakse needsamad rätikud osadeks ja antakse hauakaevajatele. Vastkaevatud haua juures asetatakse ikka veel lahtine kirst pingile. Omaksed jätavad lahkunuga hüvasti ja mõnikord tehakse ka ühispilt. Matusefotode suhtes pole Siberi eestlased sugugi ühel meelel: kui ühtedele tähendab matu- 


\section{Anu Korb}

sefoto mälestust lahkunust, siis teised püüavad fotode tegemist või vähemalt nende omamist vältida (vt ka Ristolainen 2004: 262). Mehed tõstavad seejärel kirstule kaane peale ja naelutavad selle kinni. Vaid halva ilma korral suletakse kirst juba kodus. Neli meest haaravad kirstu alla asetatud käterätiotstest ja kirst lastakse hauda. Matja loeb haua juures ettenähtud kirjakoha ja viskab oma kolm peotäit mulda surnule järele. Seejärel viskavad kõik matuselised kolm peotäit mulda.

Enamasti lastakse kirst hauda laulu saatel, sageli lauldakse seejuures "Mu rahukamber valmis...". Järgnevate laulude hulk ja valik pole kindlalt ette määratud, matja valib need oma äranägemise järgi. Samaaegselt laulmisega hakkavad mehed hauda kinni ajama. Lahkunu meessugulased pakuvad peielistele sealsamas surnuaial viina ja kompvekke-küpsiseid. Ka hauale valatakse veidi viina ja puistatakse küpsiseid. Kui jupp käterätiriiet jääb järele, seotakse see perekonna hauaplatsil mõne risti külge. Hauale asetatakse kunstpärjad, suvel ka elavad lilled. Küünalde süütamine kalmul, mis Kodu-Eestis üsna tavaline, pole siberlastel juurdunud. Surnut saatma võib tulla igaüks, peielauda lähevad vaid eelnevalt kutsutud.

\section{Järgmise surnu ennustamine, püüd tagada pere heaolu}

Ühelt poolt püüti mitmesuguste märkide järgi järgmist surnut ennustada, teiselt poolt taheti oma tegevusega uut surma võimalikult edasi lükata ning peret õnnetuse eest kaitsta. Märke-endeid jälgiti kogu suretamis- ja matuseperioodi jooksul.

Vaadati surnu välimust, et siis selle järgi kogukonnaliikmete edasist saatust teada saada:

Seda räägiti ikka, et kui [surnu] on nõrk, ei ole justku kange, siis ruttu sureb järel. Naisterahvas sureb ära: kui on parem jalg pikem, meesterahvas sureb [järgmisena]. A kui on pahem jalg pikem, siis naisterahvas sureb tema järel. Vot nii. A meesterahval tähendab seda: kui on pahem jalg pikem - naisterahvas sureb; kui parem - meesterahvas (CD-0010 (53) < Kovaljovo k - Anu Korb < naised, s 1913 ja 1905 (1997)). 
Hoolega jälgiti ka matusepäeva ilma:

Kui tuiskas, siss üteldasse, et [surnu] oli õel inemene, a kui illusa ilma om, siss üteldasse, et oli hää inemene. A ei, tuu ei ole õigus, ilma ma ei usu. [---] Siin mitu tükki on matetu, niikangede ilusa ilma om, ta ol'l nii halb inemine, nii et halvembat vaja es ole. Ja kes ol'l hää inemine, tollel ol'l halva ilma ja (FA DAT 48 (16) < Tara raj, Jurjevka k - Anu Korb < naine, s 1928 (1996)).

Vaadatass, et kostpuult tuul om. [Kui on vastu matuserongile,] siss saa ruttu surnu järgi. A kui takast tuul olevat, siss lätt kauga, pikepalt aiga (FA DAT 48 (14) < Tara raj, Jurjevka k - Anu Korb < naine, s 1928 (1996)).

Kui tuul on vasta, siis ta jätab õnne kodu kõik, a kui tuul takka, siis viib õnne kaasa sinna (CD-0011 (64) < Kovaljovo $\mathrm{k}$ - Anu Korb < naine, s 1916 (1995)).

Matuserongile vastutulija järgi ennustatakse kogu Eestis järgmist surnut. Tuntud on see ka Siberi eestlastel:

Kui surnule naisterahvas vastu tule, saa naistesurnut [järgmisena] (EFA II 2, 143 (13) < Semjonovka k - Anu Korb < naine, s 1919 (1995)).

Seevastu surnurongile vastutulijale toidu või joogipoolise pakkumist, erinevalt Lõuna-Eestist Siberis, ei tunta (vt Torp-Kõivupuu 2003: 76). Võimalusel püütakse surnurongi teelt kõrvale hoida.

Ennustatakse ka surnuaial juhtunu järgi:

Meil pannakse niisugust asja tähele. Kui surnu haua kinniajamise aegu jääb mulda järele, ei lähe hauda ära, siis ütlevad, saab külas jälle surm olema - kas sellessamas peres või kellegi teise peres (RKM II 291, 470 < Ülem-Bulanka k-Rosalie Ottesson, s 1899 (1972)).

Seda vaatavad, kis viimane surnuaia värava kinni paneb, kas meesterahvas või naisterahvas, siis seda surnut saab (RKM II 447, 225 (25) < Ülem-Suetuki k - Anu Korb, Astrid Tuisk < naine, s 1920 (1991)). 


\section{Anu Korb}

Uskumine, et millegi koju unustamine ennustab uut surnut (vt nt Loorits 1932: 196), on tuntud ka Siberis:

Läksime matma ja lillekrooni ${ }^{10}$ kausi jätsime õue pääle. Ja naine haaras selle kausi ja viis surnuaia pääle, a ikka suri tagant järgi dekaabris. ${ }^{11} \mathrm{Ku}$ surnu maha unustab midagi, siss on ikka surnut. Silmaräti jätsiva kodu, ku Saia August suri, ja naine läks tagant järgi (EFA I 17, 86 (16) < Mihhailovka k - Anu Korb, Ell Vahtramäe < naine, s 1913 (1996)).

Mitmeid arhailisi, tänapäeval harvaesinevaid tavasid omistatakse naaberrahvastele. Näiteks:

Kui surnuga lähvad toast välja, siis toolid lü̈̈akse küljeli, et siis ei tule uut surnut (RKM II 447, 223 (20) < Ülem-Suetuki k - Anu Korb, Astrid Tuisk < naine, s 1920 (1991)).

Osa Siberi eestlasi peavad sellist kommet venelastelt ülevõetuks, kuid Eestis esines sama tava Saaremaal ja Setumaal (Väisänen 1924: 216), tuntud on see ka soomlastel, karjalastel ja vepslastel (Vuorela 1977: 624; Konkka 1985: 58).

Surnurongi möödumisel tuli katkestada igasugune tegevus:

Kui pere lauas sõi ja sel söömise ajal trehvas surnuga mööda minema, sööjad jätsivad söömise katki, panivad lusika või kahvle või leiva laua peale. Kui surnuga saadi mööda, hakati jälle sööma. Räägiti, et siis surm ei vii meie söögiisu ära ega ka leivaõnne majast (RKM II 291, $470<$ Ülem-Bulanka k Rosalie Ottesson, s 1899 (1972)).

Analoogiline oli lugu ka loomade söötmisega:

Kui surnuga mindas, siss loomale ei tohi midagi viia ette, et see läheb surnule. Ei hobsele kaaru, ei midagi (EFA II 2, 145 (27) < Semjonovka k - Anu Korb < naine, s 1919 (1995)).

Ühelt poolt võib surnurongi möödumisel tegevuse katkestamises näha austust lahkunu vastu, teisalt on selline käitumine kindlasti seotud iidse uskumusega, et surnu võib elavate käekäiku mõjutada. 
Anu Korb

\section{Abinõud surnukartuse vastu. Püüd leina leevendada}

Surma suhtuti Siberi eesti külakogukonnas küll kui loomulikku protsessi, kuid ikkagi on nii surma kui ka surnut omajagu kardetud. Seetõttu on kujundatud välja abinõude kompleks, mis pidi aitama surnukartusest vabaneda ja leevendama lähedaste leina. Põhiosa neist toiminguist on seotud kas surnuga vahetu kontakti loomisega (surnut tuli katsuda) või surnu kasutuses olnud esemetega, näiteks:

Kui surnu viiakse ära, tuleb istuda ruttu selle pingi peale, kust ta ära viidi, siis surnut ei karda... (RKM II 459, 131 (58) < Kaseküla k - Anu Korb < naine, s 1925, ja mees, s 1923 (1993)).

Ja too palajas, mis on olnu surnu all - kui tolle peal magad, siis ei karda enam [surnut] (EFA II 1, 7/8 (15) < Zolotaja Niva k - Anu Korb < naine, s 1916 (1995)).

Eespool kirjeldatud tõrjemaagilised toimingud on tuntud ka KoduEesti traditsioonis, kuid Siberist on teada ka mõned Eestimaal tundmatud võtted surnukartusega toimetulemiseks:

Selle eest on kole ia rohi, ku kardad [surnut]. [---] Mina mammad nii kõvasti kartsin, et kole kohe. Ja Lindat kartsin kõvasti. [---] No ma ei tiadnud. A pärast Genka babuška ${ }^{12}$ ütles mulle: "Ku tuleme sealt surnuajast tagasi, jookse tuppa, võta saslungas ${ }^{13}$ eest ära ja vaata suurde ahju. Ei hakka sa kartma." Ja mamma suri ära, viis päeva oli minuga siin ja ma kogu aeg kodu magasin. [---] Ja nü̈̈d mina ei kardagi (CD-0007 (13) < Vana-Viru k - Anu Korb < naine, s $1924(1997))$.

Üsna levinud vahend nii surnukartusest jagusaamiseks kui ka surnu tagaigatsemise vastu on Siberi eestlastel surnuaia muld:

Ja ku sa surnut pelgäd, võid är rohitsedä. [---] Surnuaia pääle piat minema, ei tohi taade kaia ja kellekiga ei kõnele. Mine surnuaia pääle, loe Meie Isa palve ja võta säält tuda maad. [Mamma] oll iks vast puul pange tuda maad [võtnu], suur 
Anu Korb

kastrul tel ${ }^{14}$ oll võetu, sekäs segi, sinna valetu tuda vett ja siss ta oll är saistanu. Ma tulli kodu ja jõi kruusi toda vett är ja mõssi pää seostsaandik är ja lätsi teki alla. Ku hää ja kerge mul oll (FA DAT 26 (1) < Semjonovka k - Anu Korb, Indrek Kaimer < naine, s 1918 (1995)).

Mina matusse ajal nägin, et üks laseb teisele mulda krae vahele. Savine muld oli ja teisel puhtad riided seljas. Ma mõtlesin, et mis ta nõnna tieb, aga arvati, et unustab ta [surnu] kohe ära siis (RKM II 447, 303/4 (26) < Ülem-Suetuki k - Anu Korb, Astrid Tuisk < naine, 59 a (1991)).

\section{Peielaud, toidu pakkumine}

Kagu-Eesti matusetraditsiooni kuulub tänapäevalgi kollektiivne toidukraamiga abistamine (Torp-Kõivupuu 2003: 73). Enamikus Siberi eestlaste kogukondades tuleb põhiosa matuselisi tänapäeval matustele omapoolse söögi- ja joogipooliseta. Mõnes vanemas Siberi külas oli siiski veel 1990. aastate paikugi kombeks matusemajja söögikraami viia:

Viivad matusemajasse, kis annab võid ja kuort. Enamus katsub ise saada, ei viida väga. Aga Pulanis viivad matustele üks ühte ja teine teist. Kas on sul omal või ei, ikka viivad (RKM II 449, 52 (69) < Ülem-Suetuki k - Anu Korb < naine, s 1936 (1992)).

Mõned informandid kinnitasid, et toidukompsus pidi varemalt kindlasti olema ka leib:

Kui lähme matusele, leigatakse leiva nukk ära. Mujale ei viidagi leiba, a matusele on mood viia (RKM II 460, 371 (9) < Kaseküla k - Astrid Tuisk < naine, 64 a (1993)).

Siberi eestlastel pakutakse tänapäeval surnuaial haua kinniajamise juures lahkunu mälestuseks viina ja maiustusi, sama on tuntud ka Võrumaa matusekombestikus (Torp-Kõivupuu 2003: 143). Kogu surnuaiale kaasavõetud toidukraam tuleb kohapeal ära tarvitada. Vanasti polnud lubatud ka matusejärgselt peiesöömingult toidujääke tagasi tuua, need tuli jagada matuselistele või santidele (Mikkor 2001: 135). Kuna Siberis on peielaud kodus, pole toidu ülejääk probleemiks. 
Anu Korb

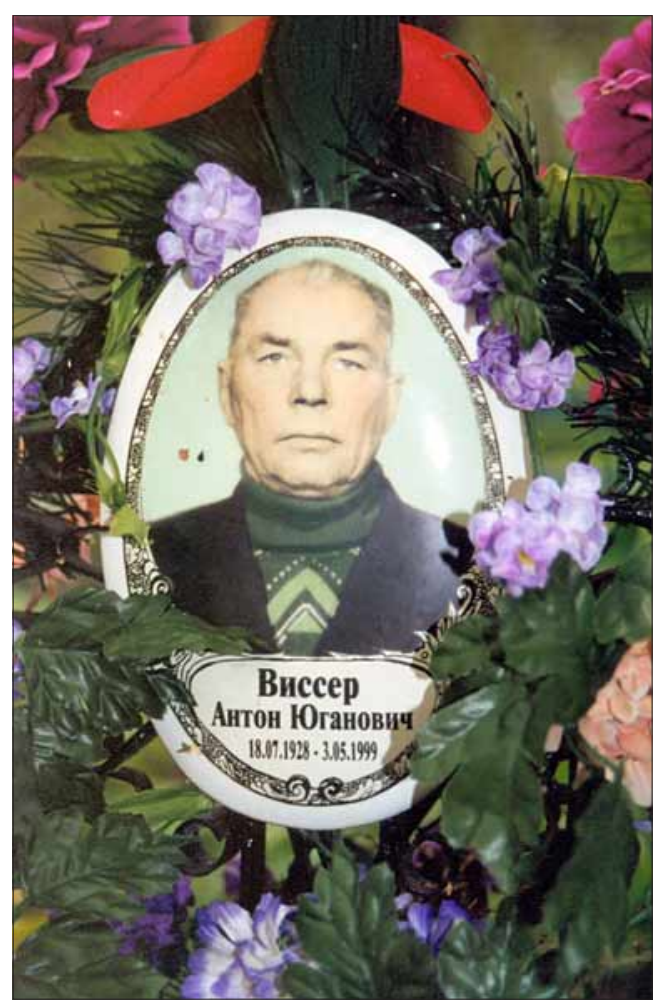

Foto 4.Anton Visseri haud Ülem-Suetuki küla surnuaial. Astrid Tuisu foto 2000 (ERA, vf 3623).

Tänapäeva Eesti külas jõutakse pidada traditsioonilisi matuseid suhteliselt rikkaliku toidulauaga. Kombekohaste matuste pidamine on prestiiži küsimus. Varem pakuti nii Kodu-Eestis kui Siberi eestlaste juures matuselistele süüa kaks korda, tänapäeval piirdutakse üldjuhul ühega (vt ka Mikkor 1992: 170-171). Peielaud on ka Siberi eestlastel suhteliselt rikkalik. Kohustusliku peietoiduna nimetatakse mitmel pool Siberis eesti kapsaid. Peremehe või perenaise matusteks tapetakse mõni suurem loom. Rituaalne loomavõi linnutapmine matusteks on tuntud olnud nii Eestis kui ka paljude teiste rahvaste juures (vt nt Salve 2000: 130). Üldjoontes Siberi eestlaste peielaud pühade ja tähtpäevade puhul kaetud pidulauast ei erine. Sooja toidu kõrval on nüüd peielaual ka erinevad salatid, 


\section{Anu Korb}

pelmeenid, puuviljad, kompott, mineraalvesi. Alkoholist pakutakse peietel tavaliselt poeviina (vrd Torp-Kõivupuu 2003: 83), mitte Siberis üldlevinud kodutehtud samagonni. Lahjemat sorti alkohol (vein, õlu, liköör) Siberi eestlaste peielauale ei kuulu.

Tavaliselt peetakse Siberi eestlaste peied lahkunu kodus - selleks koristatakse ruumid kohe surnu väljaviimise järel. Osa inimesi jääb koju toidulauda sättima. Peielauda sõidetakse kalmistult autodega, mõnikord on rahva sõidutamiseks tellitud buss. Matusejärgne kätepesemine enne peielauda istumist on üldine komme, soojemal ajal pestakse käsi õues.

Siberi eestlaste peielauas tänapäeval surnule kohta ei jäeta, nagu Kodu-Eestis tavaliselt kombeks. Surnu jaoks asetatakse kuhugi kõrvale klaas viinaga, peal leivatükk. Mõnedes Siberi kogukondades, näiteks Omi jõe piirkonna külades, on tänapäeval kombeks katta matuselaud kahvliteta, seda peetakse venelastelt ülevõetuks:

Venelastel on see, [et] panevad [matuselauale] lusikad. Enne eestlased panivad kahvlid, a nü̈̈d läksid ka vene usku. ${ }^{15} \mathrm{Ma}$ andsin oma valgete peadega kahvlid ära. Mul pole neid enam vaja, matusel pole vaja kahvleid panna (EFA II 2, 194 (10); EFA II 1, 265/6 (9) < Ivanovka k - Anu Korb, Ell Vahtramäe < naine, s 1910 (1995)).

Kahvel iseenesest on muidugi suhteliselt uus söögiriist, aga peielauas terariistade vältimise taga võib olla vana uskumus.

Kui Siberis kõik korraga peielauda ei mahu, süüakse kordamööda. Enne pakutakse süüa võõramale ja kaugemalt tulnud rahvale, mõnikord kaetakse esimene peielaud meestele, teine naistele. Tavaliselt loeb matja kõigepealt söögipalve. Paljurahvuselises külas võib ka Siberi eestlase matuselaual kohata õigeusklikel ja Eestis setudel üldtuntud rituaalseid toite, nagu nt kutja ${ }^{16}$ ja pliinid meega. Mahakukkunud toidunõu või söögipala pole matuselauas lubatud üles võtta:

Kui surnupidu ${ }^{17}$ on, midagi maha satas, kas leivaraas või kahvli, toda puttu ei tohi, et surnu om ka siis üten lauan (EFA I 18, 111 (32) Estonka k - Ell Vahtramäe < naine, s 1914 (1996)).

Mahakukkunud toidupala arvati kuuluvat lahkunu hingele (SirijosGiraite 1971: 27). Peielised lahkuvad kohe pärast söömist, esimeses vahetuses lauas istunud ei jää teiste söömise ajaks peiemajja. 


\section{Kalmistud}

Igas Siberi külas on tänapäeval oma surnuaed. Asunduste algusaegade esimesed surnud maeti tavaliselt naaberkülla. Nüüd on mõnes külas koguni mitu surnuaeda, näiteks eesti-saksa segakülas Semjonovkas eestlastel ja sakslastel eraldi. Mõnes surnu-

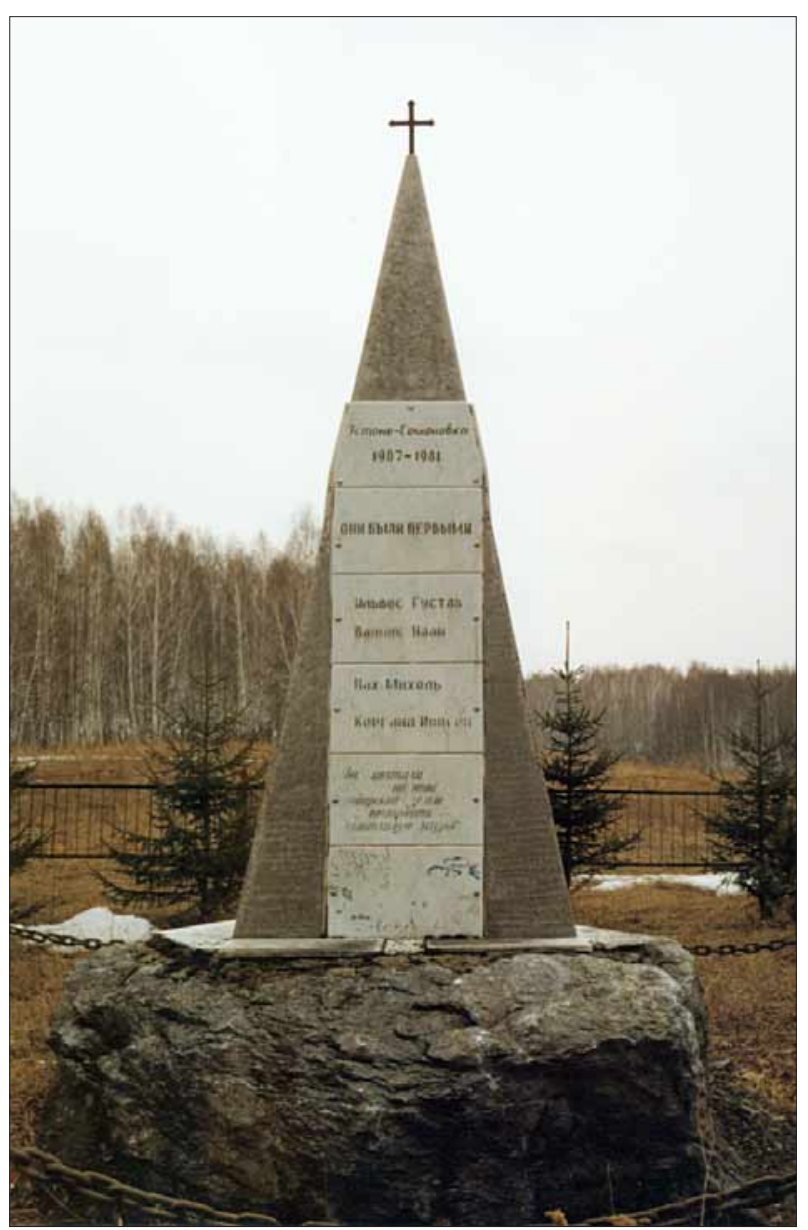

Foto 5. Küla asutajate, represseeritute ja Teises maailmasõjas hukkunute obelisk Novosibirski oblasti Estono-Semenovka küla surnuaial. Anu Korbi foto 1998 (ERA vf 925). 


\section{Anu Korb}

aias on üks pool eraldatud luterlastele, teine pool õigeusklikele (näiteks Zolotaja Nivas, Tara rajoonis Jurjevkas), teisal valiti matmispaik rahvuse järgi (näiteks eesti-läti segakülas Kovaljovos maeti surnuaia ühte ossa lätlased, teise eestlased). Tänapäeval, kui segaabielud on tavalised, enam nii ranget vahet ei peeta. Venelaste haudade läheduses on sageli väike lauake ja pingid mõlemal pool lauda, eestlaste haudade juures on enamasti vaid pink.

Enamikus Siberi eesti külade surnuaedades on tänapäeval mälestusmärk Teises maailmasõjas langenuile, samale mälestuskivile võidi hiljem raiuda ka represseeritute nimed. Novosibirski oblasti nüüdseks kadunud Estono-Semenovka küla surnuaiale aga püstitasid külaelanikud ise oma lahkunud kaaslastele monumendi, millel nii küla esmaasutajate, represseeritute kui ka Teises maailmasõjas hukkunute nimed (foto 5).

Siberi eesti külade kalmistud on enamasti metsatukas, vene külade omad lagedal väljal. Stepialadel elavad eestlased on kalmistule ka ise puid-põoosaid istutanud. Ses osas toimivad Siberi eestlased kodueestlastega sarnaselt. Kalmistuväravad on enamasti korralikud, metallist, kuid aia või tara asemel piirab kalmistut sageli lihtsalt kraav, et loomad ligi ei pääseks.

Kalmistute korrastatus on külati üsna erinev. On külasid, kus hauad kõrge rohu ja rägastiku seest väljagi ei paista (nt Koidula), teisal korraldatakse kalmistul koristuspäevi ja korrastatakse eranditult kõik hauad. Näiteks Novosibirski oblasti Nikolajevka külakalmistul tehti hauad korda kevadel enne suvistepühi.

Hauatähised erinevad Siberi eestlastel külati ja ajastuti. Varem oli tavaline päitsisse asetatud puurist. Mõned vanemad inimesed on ka tänapäeval ise oma hauale just puuristi soovinud. Kaua selline rist muidugi vastu ei pea. Üsna palju kasutatakse ka raudriste, mille kuju ja töötluse aste sõltub kohalike meistrite maitsest ja oskustest. Tänapäeval on levinuim hauatähis paamjatnik - metallist või betoonist pisiobelisk. Paamjatnikul on sageli punane viisnurk ja lahkunu foto. Ladina tähtedega kirjutatud eesti nimesid on hauatähistel võrdlemisi harva. Sageli ei oska moonutatud vene nimekuju tagant eesti nime ära tundagi. Perekonnaplatsi ümbritseb üldjuhul raudaed. Tänapäeval põhjendatakse hauaplatsi ümber aia rajamist selle loomade eest kaitsmise vajadusega. Üksikud hauaplaadid on toodud Eestimaalt ja need erinevad kalmistu üldpildist oluliselt. Eestimaa eestlase 
Anu Korb

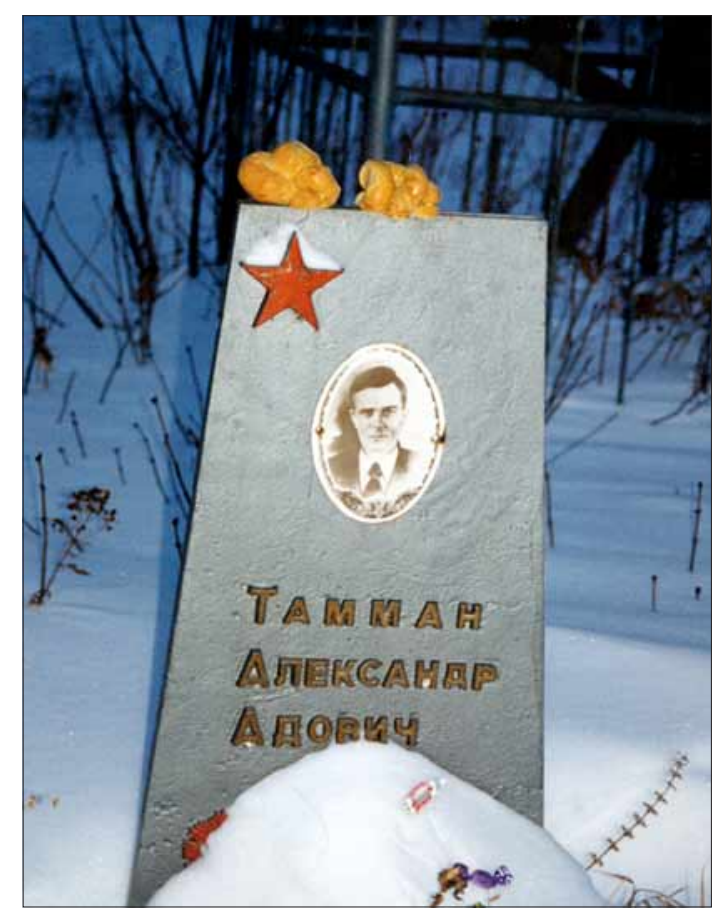

Foto 6. Aleksander Tammani haud Tsvetnopolje külakalmistul. Hauakivil saiakesed ja kompvekid. Anu Korbi foto 1997 (ERA, of 562).

hauatähisel pole tavaliselt lahkunu fotot, olen seda tava märganud vaid mõnes kitsas piirkonnas, näiteks õigeusklike kihnlaste juures. Siberi eestlased hindavad kõrgelt Eestimaa kalmistukultuuri, kuid tahavad saada maetud siiski koduküla surnuaiale omade juurde.

\section{Surnute mälestamine}

Õigeusklikelt venelastelt on Siberi eestlased nüüdseks üle võtnud surnute mälestuspäevad, mida nad varem ei tundnud. Nüüd tähistatakse üheksa ja 40 päeva, samuti poolaasta ja aasta möödumist surmast. 
Anu Korb

Ku om ütessa ööd-päiva surmast, siss hauakaebja ja lugeja ja omad kutsutass [külla], a ku om 40 ööd-päiva, siss kutsud kogu küla. Ja aastapidusid ka pidasiva (EFA I 17, 64 (30) < Estonka k - Anu Korb, Astrid Tuisk < naine, s 1938 (1996)).

[Surnut mälestatakse] ühessa päiva ja nelikümmend päiva, puul aastat ja aasta [hiljem] ja rohkemb enamb ei. [---] Noh, seal mõned omatsed - käime surnuaian ära tema havva pääl ja. Võtame leibä, liha, petšenjet,$^{18}$ kompvekke ostame, mune võtame - niisugust sü̈̈ki. Ja viil päälegi viin om kah. [---] Seal tolle havva man [sööme]. No seal on meil ligidalt omatsed pallalt, a kodu siss on söögilaud (FAM 76 (33) < Mariinski raj, Jurjevka k - Anu Korb, Astrid Tuisk < naine, s 1909 (1994)).

Surnu mälestuspäeval käiakse tavaliselt hommikupoolikul väikese seltskonnaga, ainult lähimad sugulased, surnuaial. Surnuaeda minek on Siberis teedelagunemise aegu üsna keeruline. Põhiosa külarahvast ja mujal elavatest lähisugulastest koguneb surnut mälestama kodumajja. Riietus on pidulik: meestel ülikonnd ja valge särk, naistel enamjaolt tume kleit. Elutuppa kaetud pika laua taha sageli

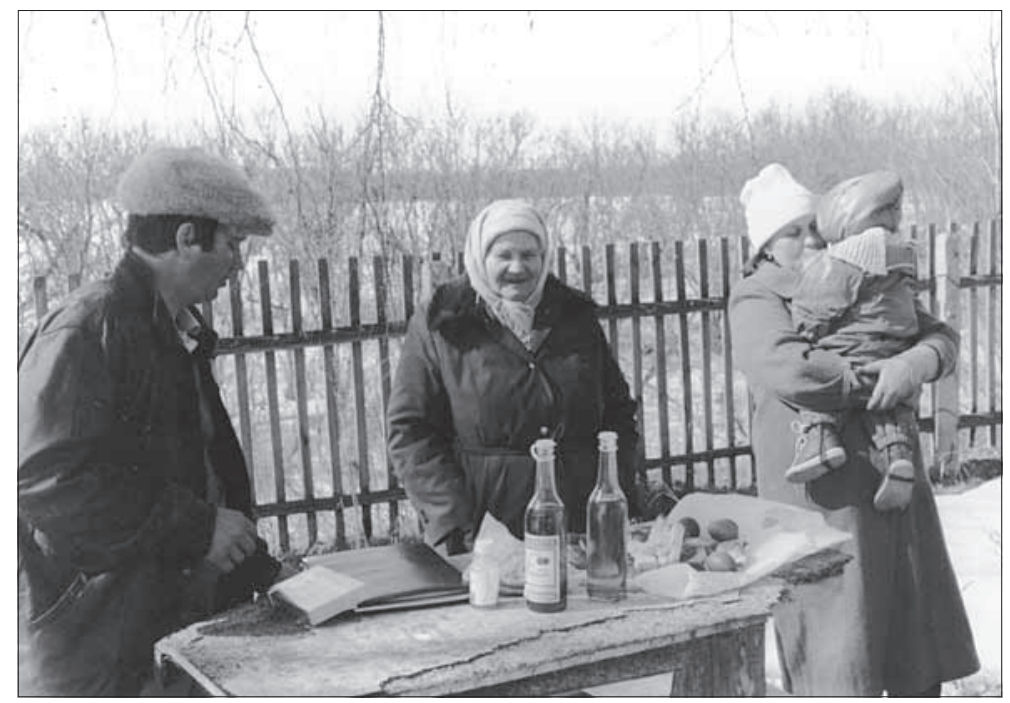

Foto 7. Omaste mälestamine lihavõttepühadel Mihhailovka küla surnuaial. Anu Korbi foto 1996 (ERA, mf 15 811). 
kõik korraga ei mahu. Vastavalt vajadusele süüakse mitmes vahetuses. Esmalt võetakse lahkunu mälestuseks pits viina. Kui laual on tavanditoit (pliinid meega või kutja), võetakse natuke seda. Järgnevad soe praad ja suupisted-salatid. Paari tunniga on kogu mälestussöömaaeg läbi.

Varem oli Siberi eestlastel tähtsaim esivanemate mälestuspäev jaanipäev ning esimeste põlvkondade Siberi eestlased ei tundnud haudadel söömist ega hauakääpale toidu panemist. Tänapäeval käivad Siberi eestlased kalmistul ka suviste- ja lihavõttepühadel. Suviste- ja lihavõtteaegne surnuaial käimine on Kodu-Eestis tuntud vaid ortodokssetel setudel (vt Hiiemäe 1984: 213). Ka Venemaa riiklikul pühal 9. mail, mida tähistatakse võidupühana, on Siberi eestlastel kombeks surnuaial oma meessugulasi mälestada, sealjuures ei ole mingit tähtsust nende seosel sõjaga. Venelaste eeskujul on Siberi eestlased hakanud tähistama veel vanemate mälestuspäeva radiitelskit, mis on tänapäeva Venemaal töövaba päev:

Radiitelski den' on peale paska ${ }^{19}$ nädal, surnuaiapüha. Venelased lähevad leivakottidega, seal pominaitavad ${ }^{20}$ (EFA II 2, 57/8 (33) < Zolotaja Niva k - Anu Korb < naine, s 1916 (1995)).

Nüüd on Siberi eestlastelgi surnuaiale minnes sageli toidukomps ühes:

Et me surnuaeda ennem leivakoti ühes võtsime, seda ei olnud. Peale sõda tuli. Ja nü̈̈d - lähme jaanipäeval või jõulul või suvistepühal, kõik on ühes, viin on ühes. Kõige rohkem on suvistepühal. Iga haua peal loeme issameie ära, iga sõbra ja sugulase haua juures. [---] Leivakott on ikkagi ühes (RKM II 460, 317/8 (10) < Kaseküla k - Astrid Tuisk < naine, s 1921 (1993)).

Tänapäeval panevad Siberi eestlasedki hauakääpale kompvekkeküpsiseid ja mitmesuguseid küpsetisi. Meesterahva hauale asetatakse lisaks klaas kangema kraamiga, vahel valatakse viin otse kääpale.

Mõnes Siberi eestlaste kogukonnas on tavaks ka pühapäeviti surnuaial käia. Astutakse läbi tuttavate-omaste haudade juurest, sageli puututakse sealjuures käega risti või hauasammast. Naised istuvad mõne kalmu või surnuaia värava juures pingil ning laulavad surma- ja matuselaule. 


\section{Anu Korb}

Surnuaial küünalde põletamise komme, mis Eestimaal järjest enam levib, pole siberlastel juurdunud - küünlaid pole sageli kohalikus kaubanduses saadagi. Jõululaupäeval ja vana-aastaõhtul surnuaias käia pole siberlastel sageli võimalikki - tee lükatakse lahti vaid matusteks.

\section{Kokkuvõtteks}

Võrreldes teiste peretraditsioonidega on matusekombestik olemuselt suhteliselt konservatiivsem ning püsivam. Siberi eestlaste matusekombestik võimaldab jälgida, kuidas toimib kogukond usulise süsteemi purustamise olukorras - missugune osa säilib ja mis paratamatult muutub. Samuti on võimalik üldistada, missugused kombestiku osad muutuvad keskkonna paljurahvuseliseks muutudes.

Külakogukonna matusetalitus on suuresti vanemate inimeste sotsiaalse kontrolli all: väljakujunenud tavade eiramist pannakse pahaks ja turvalisem tundub teha nii, nagu enne tehtud. Vanade tavade järgimine aitab säilitada omaste hingerahu: vanaviisi talitades peaks kadunu rahule jääma. Siberi eestlased tahtsid varem ja tahavad nüüdki saada maetud luteri kombe kohaselt, kuid ühiskondlikpoliitilised olud (kirikuelu keelustamine, vaimulike väljasaatmine ja vaimuliku kirjanduse hävitamine) pole traditsiooni soosinud. Ometi maetakse põhiosa Siberi eestlastest nüüdki veel jumalasõnaga.

Matusetalituse läbiviimine läks pärast vaimulike väljasaatmist isehakanud või külaelanike poolt määratud matjate - vanemate naiste - kätte, keda väljasaatmine otseselt ei ohustanud, ja jäigi naiste pärisosaks. Matjad tundsid üldjoontes kogukonna matusetraditsiooni, see levis kogemuslikult ja suuliselt, kui polnud käepärast vastavat kirjandust. Kombetalituseks vajalikke tekste-laule kirjutati maha sealt, kust võimalik, näiteks poollagunenud raamatutest, käsikirjalistest kaustikutest, võimalusel ka Eestimaa sugulaste matustelt saadud laululehtedelt. Matjad ongi peamised kogukonna matusekombestiku kujundajad. Nemad valivad ka tseremoonia juurde sobivad ilmalikud ja vaimulikud laulud ning suunavad kombestikku. 
Anu Korb

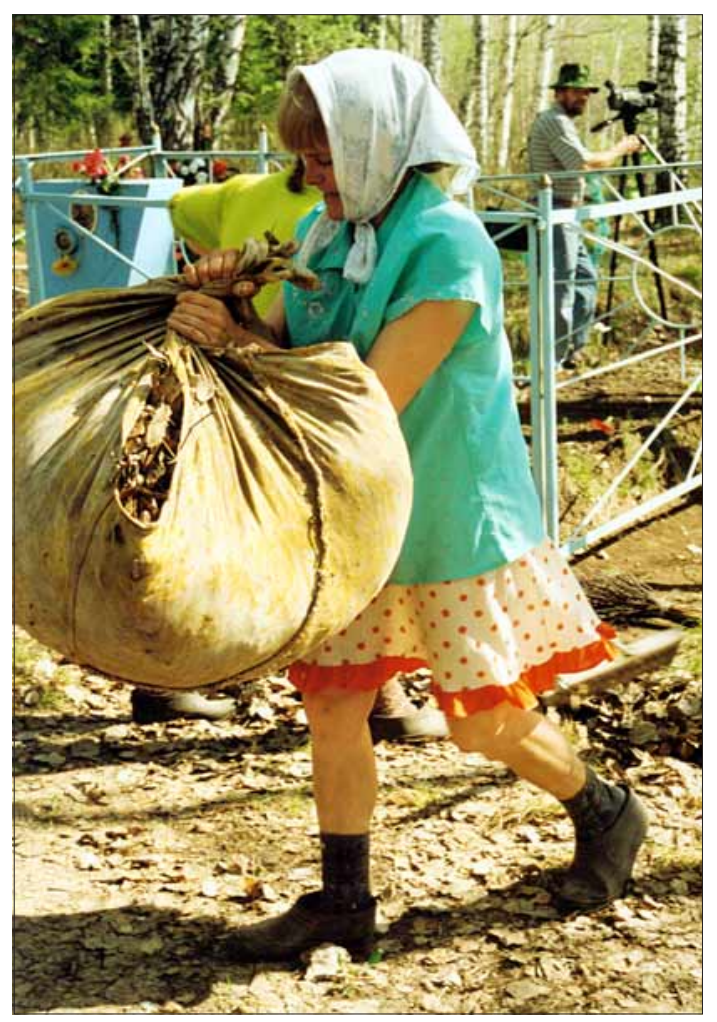

Foto 8. Larissa Rikman Nikolajevka külakalmistut koristamas. Astrid Tuisu foto 1999 (ERA, vf 2893).

Siberi eestlaste surma- ja matusekombestikus võib täheldada ühelt poolt tahet järgida esivanematelt päritut, näiteks surnu korrastatakse traditsioonilisel viisil kodus, matustele kutsutakse, lahkunu saadetakse ära kodunt ja pärast kaetakse ka peielaud kodus. Eestimaal hilisemal ajal juurdunud kombed, näiteks kalmuküünlad ja elavatest lilledest pärjad, pole Siberi eestlaste traditsiooni jõudnud. Jõululaupäeval kalmistul käimine pole siberlastel sügava lume tõttu sageli võimalikki.

Teisalt võetakse tänapäeval mitmekultuurilises keskkonnas elades paratamatult üht-teist üle naabritelt, peamiselt dominantkul- 
Anu Korb

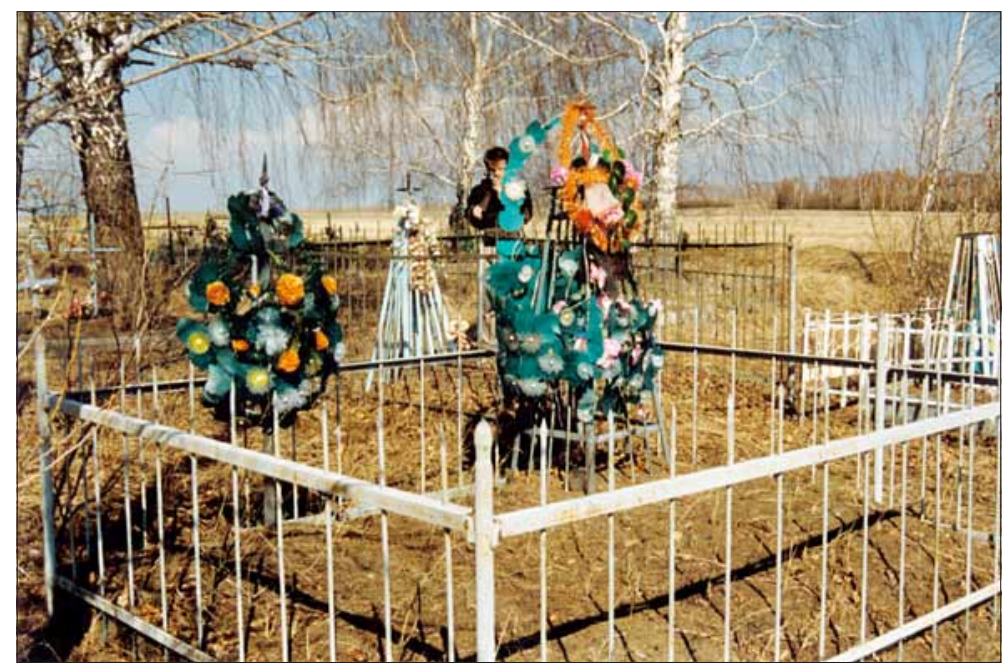

Foto 9. Vaade Oravaküla kalmistule. Anu Korbi foto 1998 (ERA, vf 1037).

tuurilt: peielaual on venelaste tavanditoite, tähistatakse üheksa ja 40 päeva möödumist surmast, kalmistul käiakse ka lihavõtte- ja suvistepühadel, 9. mail ning vanemate mälestuspäeval radiitelskil. Siberi eestlaste hauaplatsid sarnanevad üha enam kohalike venelaste omadega: hauaplatse ümbritsevad raudaiad, mälestussambad ja kunstpärjad on kohalike meistrite töö ja erinevad Kodu-Eesti omadest.

Siberi eestlased eristavad matusekombestikust rääkides ise üsna selgesti oma ja võõrast, on teadlikud võõrastest elementidest, alustades sageli kombestikukirjeldust sõnadega: Nü̈̈d on see vene mood võetud. Vanemad inimesed eelistavad toimida esivanemate kombel ja võtavad võõraid tavasid aeglasemalt omaks. Mitmekultuurilises keskkonnas on aga naabrite mõningate kombestikuelementide ülevõtmine paratamatu. Ülevõetu mõju on märgatavam segaperedes ja paljurahvuseliste külade eestlastel. Matusetavade ühtlustumisele viitab ka erineva usulise taustaga ja eri rahvusest matjate vastastikune matma kutsumine ja talituse läbiviimine vene keeles, millest on nagunii saanud põlvkondi ühendav keel. 
Anu Korb

\section{Kommentaarid}

1 Piinles (vrd vene k мучиться).

2 Siin: ka (vrd vene k $и$ ).

${ }^{3}$ Naabrinaine.

4 Ülem-Bulanka külla.

${ }^{5}$ Rotid.

6 Üldse (vrd vene k вообще).

${ }^{7}$ Alusseelikuga (vrd vene k юбка).

${ }^{8}$ Naabriperemehele.

${ }^{9}$ Käterätt.

10 Pärja.

${ }^{11}$ Detsembris (vrd vn декабрь).

12 Vanaema (vrd vene k бабушка).

${ }^{13}$ Ettetõstetav ahjuuks (vrd vene $\mathrm{k}$ заслонка).

14 Tal (temal).

15 Siin: hakkasid tegema, nagu venelased teevad.

${ }^{16}$ Venelaste matusetoit, valmistatud meeveest ja hernestest.

17 Peied.

18 Küpsiseid (vrd vene k печенье).

19 Lihavõtteid (vrd vene пасха).

${ }^{20}$ Mälestavad (vrd vene поминать).

\section{Arhiiviallikad}

$\mathrm{CD}=$ Eesti Rahvaluule Arhiivi digitaalsalvestused CD-del (alates 1997. aastast)

Disk = digitaalsalvestus, autori valduses

DV - Eesti Rahvaluule Arhiivi digitaalvideo, sh ümbervõtted filmilindilt (alates 1959. aastast)

EFA = Eesti folklooriarhiivi rahvaluulekogu (Eesti Rahvaluule Arhiivi kogu alates 1996. aastast) 


\section{Anu Korb}

FA DAT = Eesti Rahvaluule Arhiivi DAT-magnetofoni salvestused (alates 1992. aastast)

FAM = Eesti Rahvaluule Arhiivi analoogsalvestused stereokassettidel (alates 1991. aastast)

$\mathrm{H}=$ J. Hurda rahvaluulekogu (1860-1906)

RKM = Eesti TA Fr. R. Kreutzwaldi nim (Riikliku) Kirjandusmuuseumi (nüüd Eesti Kirjandusmuuseumi) rahvaluule osakonna rahvaluulekogu (peamiselt alates 1945. aastast)

\section{Kirjandus}

Aho, Hannu S. 1996. "Ja sattu kerran, kun ne oli laskemassa arkkua hautaan...” Eeva-Liisa Kinnunen \& Kaarina Koski \& Riikka Penttilä \& Minttu Pietilä (toim). Vitsistä videoon: Uusia kirjoituksia nykyperinteestä. Tietolipas 146. Helsinki: Suomalaisen Kirjallisuuden Seura, lk 118-136.

Eisen, Matthias Johann 1920. Eesti uuem mütoloogia. Tallinn: Rahvaülikool.

Jannsen, Johann Woldemar 1874. Mõned vanad Läti ja Eestimaa pruugid surnute matmise juures. Eesti Postimehe lisaleht 50, 51, 52.

Hiiemäe, Mall 1984. Eesti rahvakalender III. Tallinn: Eesti Raamat.

Hupel, August Wilhelm 1777. Topographische Nachrichten von Lief- und Ehstland. 2. Riga: Johann Friedrich Hartknoch.

Jürgenson, Aivar 2000. Kirik ja kool Siberi eesti asundustes. Priit Raudkivi (toim).Acta Historica Tallinnensia: Ajaloo Instituudi ja Eesti Teaduste Akadeemia ühisväljaanne = Official publication of the Institute of History and the Estonian Academy of Sciences 4. Tallinn: Teaduste Akadeemia Kirjastus, lk 31-48.

Kallatsa, Miika 1994. Karismaattiset naiset - Inkerin kirkon pelastus. Verso 6-7, lk 26-27.

Kemppinen, Iivar 1967. Haudantakainen elämä karjalaisen muinaisuskon ja vertailevan uskontotieteen valossa. Karjalan Tutkimusseuran Julkaisuja 1. Helsinki: Karjalan Tutkimusseura.

Korb, Anu 1996. Ei oska rääkimise moodi kõnelda: Zolotaja Niva, Semjonovka, Jurjevka, Koidula. Eesti asundused 2. Tartu: Eesti Kirjandusmuuseum.

Korb, Anu 1998. Siberi eestlaste lauluvara. Astrid Tuisk (toim). Eesti kultuur võorrsil: Loode-Venemaa ja Siberi asundused. Tartu: Eesti Kirjandusmuseum, lk 143-157. 
Konkka, Unelma 1985. Ikuinen ikävä: Karjalaiset riitti-itkut. Suomalaisen Kirjallisuuden Seuran Toimituksia 428. Helsinki.

Kõivupuu, Marju 2000. Rahvaarstid Võrumaalt: Noor ja vana Suri Hargla kihelkonnast. Võro: Võro Instituut'.

Lang, Merike 2004. Matusekommetest Kirde-Eestis 19. sajandil ja 20. sajandi algul. Mäetagused 25, lk 77-102.

Loorits, Oskar 1932. Der Tod in der livischen Volksüberlieferung. Õpetatud Eesti Seltsi Toimetised XXVI. Tartu: Õpetatud Eesti Selts, lk 170-200.

Manninen, Ilmari 1924. Setude matusekommetest. Eesti Keel III, lk 10-19.

Mikkor, Marika 1992. Kaukaasia eestlaste matusekombestikust. Heiki Pärdi (peatoim). Eesti Rahva Muuseumi aastaraamat 39, lk 167-186.

Mikkor, Marika 1994 Kaukaasia eestlaste surmakujutelmadest. Akadeemia 6, lk 1234-1267; 7, lk 1481-1496.

Mikkor, Marika 2001. Muutuvast matusekombestikust linnas ja maal. Anepaio, Terje (peatoim). Eesti Rahva Muuseumi aastaraamat 45, lk 103-146.

Moora, Aliise 1956. Eestlaste muistsest usundist. Religiooni ja ateismi ajaloost Eestis 1. Tallinn: Eesti Riiklik Kirjastus, lk 7-41.

Paulaharju, Samuli 1924. Syntymä, lapsuus ja kuolema: Vienan Karjalan tapoja ja uskomuksia. Kalevalaseuran Julkaisuja 2. Porvoo: Söderström.

Raadla, Amanda 1939. Eesti matusekommete ülevaade. Seminaritöö. Tartu: Tartu Ülikool. Käsikiri Eesti Rahvaluule Arhiivis.

Reiman, Helmi 1915. Eestlaste matusekombed. Villem Reiman (toim). Eesti Kultura IV. "Postimehe” kirjakogu 1: Tartu, lk 123-163.

Ristolainen, Tiia 2004. Surmakultuuri suundumused tänapäeval: Avalik ja privaatne. Õpetatud Eesti Seltsi aastaraamat 2002. Tartu: Õpetatud Eesti Selts, lk 244-266.

Postimees 1899, nr 196.

Salve, Kristi 2000. Mõningaid tähelepanekuid tavanditoitudest: Diferentseerimine piirkonniti ja üldistumine tavanditi. Mare Kõiva (toim). Sator: Artikleid usundi- ja kombeloost II. Tartu: Eesti Kirjandusmuuseumi folkloristika osakond, lk 121-140.

Sirijos-Giraite, Danute 1971. Surnutekultuse ühiseid jooni eesti, liivi, läti ja leedu rahvaluules ning mütoloogias. Diplomitöö. Käsikiri: Tartu Riikliku Ülikooli NSVL ajaloo kateeder.

Torp-Kõivupuu, Marju 2003. Surmakultuuri muutumine ajas: Ajaloolise Võrumaa matusekombestiku näitel. Monograafia. TPÜ Toimetised. Humaniora A 22. Tallinn: Tallinna Pedagoogikaülikool. 


\section{Anu Korb}

Viikberg, Jüri \& Vaba, Lembit 1984. Siberi põhjaeestlasi kõnetamas. Keel ja Kirjandus 3, lk 145-156.

Vuorela, Toivo 1977. Suomalainen kansankulttuuri. Porvoo \& Helsinki: Werner Söderström Osakeyhtiö.

Väisänen, Armas Otto 1924. Syntymä, lapsuus ja kuolema: Setukaisten tapoja ja uskomuksia. Kalevalaseuran vuosikirja IV. Helsinki: Kustannusosakeyhtiö Otava, lk 193-223. 